\title{
Role of Trade in India's Rising Atmospheric Mercury Emissions
}

Jetashree ${ }^{1}$, Qiumeng Zhong ${ }^{2}$, Haifeng Zhou ${ }^{1}$, Yumeng $\mathrm{Li}^{1}$, Yu Liu ${ }^{3,4}$, Jiashuo Li ${ }^{5}$, Sai Liang ${ }^{2, *}$

${ }^{1}$ School of Environment, Beijing Normal University, Beijing 100875, People's Republic of China

${ }^{2}$ Key Laboratory for City Cluster Environmental Safety and Green Development of the Ministry of Education, Institute of Environmental and Ecological Engineering, Guangdong University of Technology, Guangzhou, Guangdong 510006, People’s Republic of China

${ }^{3}$ Institutes of Science and Development, Chinese Academy of Sciences, Beijing, 100190, People's Republic of China

${ }^{4}$ School of Public Policy and Management, University of Chinese Academy of Sciences, Beijing 100049, People's Republic of China

${ }^{5}$ Institute of Blue and Green Development, Shandong University, Weihai, Shandong 264209, People's Republic of China

"Correspondence author: liangsai@gdut.edu.cn (Sai Liang).

Number of pages: 23

Number of figures: 2

Number of tables: 5 


\section{S1. Compiling Hg emission inventories}

This study focuses on $\mathrm{Hg}$ emissions from power plants, industries and $\mathrm{Hg}$ containing products in 2004, 2007, 2011, and 2014. As noted in the main text, previous studies have focused on direct $\mathrm{Hg}$ emissions in India. However, in order to maintain uniformity in the emissions estimation methods for all four years, this study employed a newly constructed $\mathrm{Hg}$ emissions inventory for the years of focus. Activities that cause direct emissions of mercury $(\mathrm{Hg})$ can be classified into those where $\mathrm{Hg}$ is released as a 'by-product' of the activity, such as combustion of fossil fuels, and those where $\mathrm{Hg}$ is used intentionally. This study followed a similar methodology to the Global Mercury Assessment 2018 ${ }^{1}$ (GMA 2018) report for calculating the 'by-product' $\mathrm{Hg}$ emissions occurring due to the use of $\mathrm{Hg}$-containing fuels or raw materials in energy/industrial sectors. The emissions from a source are calculated by multiplying the activity rate of the source with its emission factor. The activity rate refers to the amount of $\mathrm{Hg}$-containing fuels or raw materials used in production processes or the $\mathrm{Hg}$-containing commodities produced. The activity data were taken from national sources where available, and in other cases from other official sources, the details of which are provided in Tables S1 and S2. The IEA's World Energy Statistics (2018) ${ }^{2}$ was preferred for activity data of the national fuel consumption (coal, oil, natural gas, primary solid biomass) due to its level of detail regarding usage of different fuel types in separate industries (for example, the usage of coal in power plants, and in individual industry types such as the cement industry, the non-ferrous metals industry, ferrous metals industry, etc.).

The emission factors have been taken from the existing literature, and where sufficient data is unavailable, the default emission factors provided in the GMA 2018 report are used. The details of data sources of the emission factors considered are provided in Table S3. The abatement of Hg emissions in different activities were estimated following the methods provided in the GMA 2018 report. The details of the application rates of air pollution control mechanisms and their Hg reduction efficiencies are provided in Table S4. In cases where the details of abatement technologies are unavailable, the default technology profiles for the country group " 5 " to which India is assumed to belong in the GMA 2018 report, are assumed for calculating abatement of $\mathrm{Hg}$ emissions. The difference between the 'unabated' emissions and the reduction of $\mathrm{Hg}$ emissions gives the 'abated' $\mathrm{Hg}$ emissions to air.

Three sectors that intentionally use Hg are considered in this study, namely, Chlor-alkali production (mercury process), Vinyl Chloride Monomer (VCM) sector (acetylene process), and the dental sector. The details of activity data, emission factors, and technology profiles used for estimating the Hg emissions from these sectors are provided in Tables S2, S3, and S4. The emissions from Hg-containing products namely, batteries (CarbonZinc, alkaline and button cells), measuring \& control devices (specifically sphygmomanometers and thermometers in the healthcare segment), lamps (fluorescent lamps and compact fluorescent lamps), and electrical \& electronic devices that enter the waste stream after use, are accounted for in the Water and Waste sector. The Hg emissions from disposed products are accounted for in the same year during which the products are manufactured/ consumed, although practically the $\mathrm{Hg}$ emissions may occur in later years at the end of their useful life when they are disposed. Only the respective years' production/ consumption has been considered and the $\mathrm{Hg}$ emissions from stocks of previous years remaining in society are not considered. The data sources and assumptions regarding the usage and emissions from $\mathrm{Hg}$ containing products are provided in Tables S2 and S3. India does not have cinnabar resources and therefore, there is no primary mining of $\mathrm{Hg}$ in India. ${ }^{3} \mathrm{The} \mathrm{Hg}$ production from cinnabar ore category of non-ferrous metal production in the GMA 2018 report is therefore, not applicable to India.

The satellite account is then constructed by mapping the estimated source-wise emissions to the economic sectors of India. The apportionment of the energy-related emission sources to the economic sectors has been done following the concordance in the documentation ${ }^{4}$ of the GTAP database. The industrial and intentional use activities have been mapped to related economic sectors. This mapping is provided in Table S7. In this study, the satellite account is a row vector of order (1x9165) that contains the sector-wise production-based $\mathrm{Hg}$ emissions of nation sectors. The values for all nation sectors other than Indian sectors are 0 in this case, since only the $\mathrm{Hg}$ emissions occurring in India are studied. 
Table S1. Emission sources for which activity data are obtained from IEA ${ }^{2}$

\begin{tabular}{|c|c|c|}
\hline \multirow{6}{*}{$\begin{array}{l}\text { Energy Sectors } \\
\text { (Stationary combustion of fossil fuels) }\end{array}$} & \multirow[t]{2}{*}{ Coal } & Power plants: Brown Coal (Lignite), Brown Coal (Sub-bituminous), Hard Coal (Bituminous) \\
\hline & & $\begin{array}{l}\text { Industries: } \\
\text { Brown Coal - Cement Industry, Non-ferrous metals (NFM) industry, Ferrous metal industry, Other industries } \\
\text { Hard Coal - Cement Industry, NFM industry, Ferrous metal industry, Other industries }\end{array}$ \\
\hline & \multirow[t]{2}{*}{ Oil } & Power plants: Heavy fuel oil, Light fuel oil \\
\hline & & $\begin{array}{c}\text { Industries: Heavy fuel oil, Light fuel oil } \\
\end{array}$ \\
\hline & 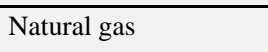 & Power plants, Industries \\
\hline & Primary solid biomass & Power plants, Industries \\
\hline \multicolumn{3}{|l|}{ Use of pet coke in Cement industry } \\
\hline Oil refining & & \\
\hline
\end{tabular}

Note: Low and high range estimates of activity data for the above categories have been calculated as per the methods outlined in the GMA $2018^{1}$ report.

Table S2. Other emission sources and their activity data

\begin{tabular}{|c|c|c|c|c|c|c|}
\hline Sectors & Units & 2004 & 2007 & 22011 & 22014 & References and remarks \\
\hline \multicolumn{7}{|l|}{ Ferrous metal production (PISP) } \\
\hline Iron and Steel (Primary production) & $\mathrm{kt}$ & 23,243 & 27,418 & 36,597 & 47,265 & Ministry of Steel ${ }^{5,6}$ \\
\hline Secondary steel production & $\mathrm{kt}$ & 23,422 & 31,753 & 43,065 & 51,408 & Ministry of Steel ${ }^{5,6}$ \\
\hline \multicolumn{7}{|l|}{ Non-ferrous metal production (NFMP) } \\
\hline Primary Copper & $\mathrm{t}$ & 401,000 & 700,000 & 670,000 & 765,569 & 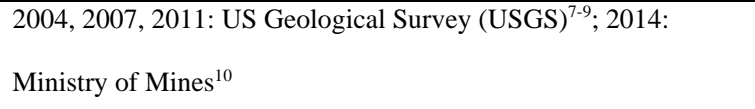 \\
\hline Primary Lead & $\mathrm{t}$ & 21,000 & 53,800 & 72,000 & 127,000 & 2004-2011: USGS ${ }^{7-9} ; 2014:$ Ministry of Mines ${ }^{11}$ \\
\hline Primary Zinc & $\mathrm{t}$ & 238,400 & 430,800 & 783,647 & 733,000 & $\begin{array}{l}\text { 2004, 2007: USGS }{ }^{7,12} ; 2011: \text { Indian Minerals Yearbook }{ }^{13} ; 2014: \\
\text { Ministry of Mines }{ }^{11}\end{array}$ \\
\hline Primary Aluminum & $\mathrm{kt}$ & 861 & 1,028 & $1,671.45$ & $2,046.56$ & 2004, 2007: USGS ${ }^{7-9,12} ; 2011,2014:$ Ministry of Mines ${ }^{11}$ \\
\hline Large scale Gold & $\mathrm{kg}$ & 3,700 & 3,000 & 2,194 & 1,441 & 2004, 2007: USGS ${ }^{7-9,12} ; 2011,2014:$ Ministry of Mines ${ }^{11}$ \\
\hline \multicolumn{7}{|l|}{ Other industry } \\
\hline Cement (excluding fuels) & $\mathrm{kt}$ & 130,000 & 170,000 & 240,000 & 280,000 & USGS $^{7-9,12}$ \\
\hline \multicolumn{7}{|l|}{ Intentional use } \\
\hline $\begin{array}{l}\text { Chlor-alkali production (mercury } \\
\text { process) }\end{array}$ & $\mathrm{t}$ & 490,000 & 308,000 & 95,000 & 42,000 & World Chlorine Council ${ }^{14}$ \\
\hline $\begin{array}{l}\text { Vinyl Chloride Monomer (acetylene } \\
\text { process) }\end{array}$ & $\mathrm{t}$ & $95,195.52$ & $108,855.89$ & $130,166.47$ & $148,845.10$ & $\begin{array}{l}\text { Values for 2004, 2007, } 2011 \text { and } 2014 \text { were estimated using a } \\
\text { constant growth rate for activity rates between 2001obtained from } \\
\text { a report by the Central Pollution Control Board (CPCB), Ministry } \\
\text { of Environment, Forest and Climate Change, Government of } \\
\text { India }^{15} \text {, and } 2015 \text { obtained from a press release by Federation of } \\
\text { Indian Chambers of Commerce and Industry (FICCI) }\end{array}$ \\
\hline Note: For all the above activities, the low & ange a & ge activity data & timated using th & ods provided in $\mathrm{G}$ & & \\
\hline $\begin{array}{l}\text { Dental sector (values of Hg emissions to } \\
\text { air) }\end{array}$ & $\mathrm{t}$ & $5.17(2.94-8.24)$ & $8.76(5.16-14.12)$ & $13.50(8.09-21.88)$ & $13.98(8.37-22.65)$ & $\begin{array}{l}\text { Estimated following the methodology in a report by an } \\
\text { environmental organization, Toxics Link }{ }^{17} \text {. All assumptions and }\end{array}$ \\
\hline
\end{tabular}




\begin{tabular}{|c|c|c|c|c|c|c|}
\hline & & & & & & $\begin{array}{l}\text { calculation procedures are as per the working in the } \\
\text { aforementioned report. } \\
\text { Percentage of Indians that have caries was assumed to be } 40 \% \text {, } \\
70 \% \text { and } 80 \% \text { in the low, intermediate and high range, } \\
\text { respectively, and } 58 \% \text { of these people were assumed to visit a } \\
\text { dentist. }{ }^{17,18} \\
\text { Population data for India in } 2004,2007,2011 \text { and } 2014 \text { was } \\
\text { obtained from The World Bank }{ }^{19} \text {. } \\
\text { The dentist to population ratio was 1:30,000 in } 2004^{20}, 1: 15,713 \text { in } \\
2007^{21}, 1: 10,000 \text { in } 2011^{22} \text { and } 2014^{23} \text {. } \\
\text { Death rate in India for the respective years was taken from The } \\
\text { World Bank }{ }^{19} \text {. } \\
\text { Only the } 15-65 \text { years age group in the total population was } \\
\text { considered in the estimation since it is assumed that Hg-free } \\
\text { fillings are used for children, and that by the age of } 65 \text {, people } \\
\text { begin to lose teeth. }{ }^{17} \text { The population data for this age group was } \\
\text { obtained from The World Bank }{ }^{19} \text {. } \\
\text { Details of the amount of Hg used in each filling is provided in } \\
\text { Table S3. The amount of non-contact amalgam generated in each } \\
\text { dental restoration is considered to be } 15 \%, 32.5 \% \text { and } 50 \% \text { of the } \\
\text { amount of mercury filling in the low, intermediate and high range, } \\
\text { respectively. }{ }^{17} \text { It is assumed that } 80 \% \text { of the people in India are } \\
\text { cremated after death }{ }^{17,24} \text {. }\end{array}$ \\
\hline $\begin{array}{l}\text { Gold recovery from e-waste (values of } \\
\text { Hg emissions to air) }\end{array}$ & $\mathrm{kg}$ & 0.004 & 0.0009 & 0.0021 & . & $\begin{array}{l}\text { This section accounts for the use of } \mathrm{Hg} \text { in recovering gold from } \\
\text { the Printed Wiring Board (PWB) fraction of e-waste. The Hg } \\
\text { emissions were estimated following the methodology and using } \\
\text { the assumptions in Burger Chakraborty et al. } .^{25} \text {; E-waste generation } \\
\text { in } 2004 \text { is assumed to be the same as the amount of e-waste } \\
\text { generation in } 2005^{26} \text {. The e-waste generation for } 2007 \text { is obtained } \\
\text { from a GTZ-MAIT sponsored study conducted by IMRB }{ }^{27} \text {, and for } \\
2014 \text { from the Global e-waste monitor } 2014^{28} \text {. The value of e- } \\
\text { waste generation in } 2011 \text { was estimated assuming a constant } \\
\text { growth rate between } 2005 \text { and } 2014 \text {. The net import of e-waste } \\
\text { was reported as } 50,000 \text { tons in } 2007^{27} \text {. This value is assumed to be } \\
\text { constant for all four years of the study. Low range and high range } \\
\text { emissions estimates are assumed to be the same as mid-range } \\
\text { estimates due to the relatively small emissions values. }\end{array}$ \\
\hline \multicolumn{7}{|l|}{ Water and Waste } \\
\hline $\begin{array}{l}\text { Compact Fluorescent } \\
\text { Lamp (CFL) }\end{array}$ & units & $36,606,010$ & $140,000,000$ & $340,000,000$ & $448,000,000$ & $\begin{array}{l}\text { 2004: estimated assuming linear growth in production volume } \\
\text { between } 2003 \text { (value obtained from a study by Toxics Link }{ }^{29} \text { ) and } \\
\text { 2005(value obtained from ELCOMA }{ }^{30} \text { ); production volumes in } \\
2007,2011 \text { and } 2014 \text { are obtained from ELCOMA }{ }^{30,31} \text {. } \\
\text { One-third of India's CFL demand is met through imports. }{ }^{29} \\
\text { Import-Export data are taken from the Export Import Data Bank }{ }^{32} \\
\text { of the Ministry of Commerce and Industry, Government of India. }\end{array}$ \\
\hline $\begin{array}{l}\text { Fluorescent Lamp } \\
\text { (FL) }\end{array}$ & units & $174,305,986$ & $190,000,000$ & $194,000,000$ & $257,000,000$ & $\begin{array}{l}\text { 2004: back-calculated from } 2006 \text { value assuming an annual } \\
\text { growth rate of } 3.3 \%{ }^{33} \text {; production volumes in 2007, } 2011 \text { and } 2014 \\
\text { are obtained from ELCOMA }{ }^{30,31} \text {. }\end{array}$ \\
\hline Sphygmomanometer & units & 255,460 & 528,740 & $1,382,500$ & $1,918,760$ & \\
\hline
\end{tabular}




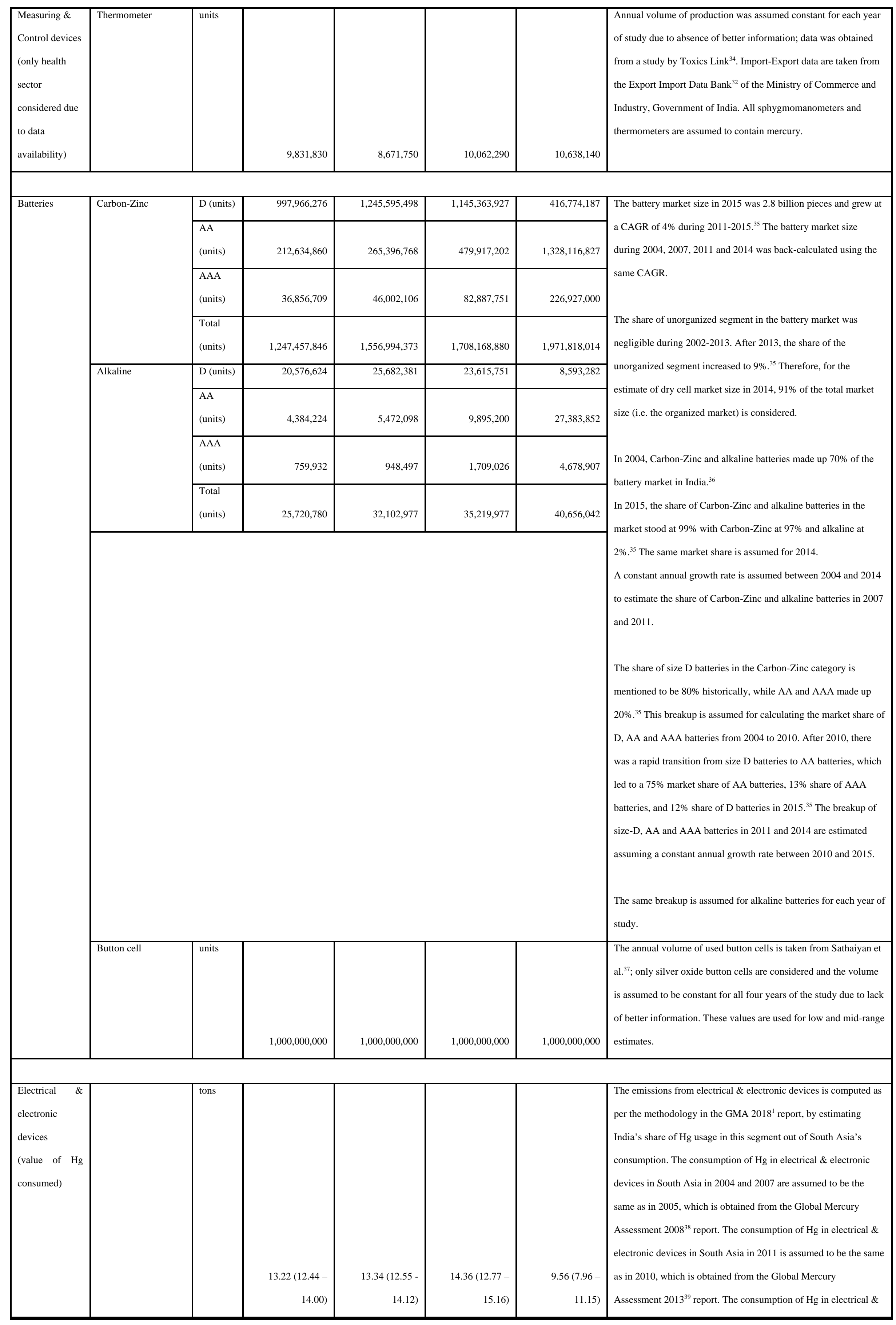




\begin{tabular}{|l|l|l|l|l|l|}
\hline & & & & & \\
& & & & $\begin{array}{l}\text { electronic devices in South Asia in 2014 is assumed to be the same } \\
\text { as in 2015, which is obtained from the GMA 2018' report. India's } \\
\text { share of Hg consumption in electrical \& electronic devices is } \\
\text { estimated using its gross domestic product at purchasing power } \\
\text { parity (GDP-PPP) for each year of the study. GDP-PPP data is } \\
\text { taken from The World Bank' } \\
\text { data are available for South Asia in the respective GMA reports } \\
\text { from which the values for India are calculated. }\end{array}$ \\
\hline \hline
\end{tabular}

Note: Values in brackets indicate low range to high range.

Table S3. Mercury (Hg) emission factors considered in this study

\begin{tabular}{|c|c|c|}
\hline 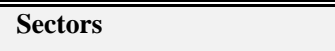 & Emission Factors & $\begin{array}{ll}\text { References and remarks } \\
\end{array}$ \\
\hline \multicolumn{3}{|l|}{ Combustion of fuels } \\
\hline \multicolumn{3}{|l|}{ Coal } \\
\hline Coal - Power plants & $0.14 \mathrm{~g} / \mathrm{t}$ (intermediate) & Value for Indian coal used in power plants taken from UNEP $P^{40}$, National Electricity Plan ${ }^{41}$ \\
\hline Coal - Industry & $\begin{array}{l}0.11 \mathrm{~g} / \mathrm{t} \text { (low), } 0.272 \mathrm{~g} / \mathrm{t} \text { (intermediate), } \\
0.376 \mathrm{~g} / \mathrm{t} \text { (high) }\end{array}$ & $\begin{array}{l}\text { Value for Indian coal used in industries taken from Burger Chakraborty et al }{ }^{25} \text { The low range estimate is the average of bituminous } \\
\text { coal samples taken from US Geological Survey }{ }^{42} \text {, the mid-range estimate is obtained from } \mathrm{CPCB}^{33} \text {, and the high range estimate is } \\
\text { obtained from Mukherjee et al. } .^{3}\end{array}$ \\
\hline \multicolumn{3}{|l|}{ Oil } \\
\hline Heavy fuel oil & $0.02 \mathrm{~g} / \mathrm{t}$ (intermediate) & Default \\
\hline Light fuel oil & $0.002 \mathrm{~g} / \mathrm{t}$ (intermediate) & Default \\
\hline \multicolumn{3}{|l|}{ Gas } \\
\hline Natural Gas & $0.005 \mathrm{~g} / \mathrm{TJ}$ (intermediate) & Default \\
\hline \multicolumn{3}{|l|}{ Biomass } \\
\hline Power plants & $1.25 \mathrm{mg} / \mathrm{GJ}$ & Default \\
\hline Industry & $1.25 \mathrm{mg} / \mathrm{GJ}$ & Default \\
\hline \multicolumn{3}{|c|}{ Ferrous metal production (PISP) } \\
\hline $\begin{array}{l}\text { Iron and Steel (Primary } \\
\text { production) }\end{array}$ & $\begin{array}{l}0.004 \text { (low), } 0.073 \text { (intermediate) and } 0.187 \\
\text { (high) } \mathrm{g} / \mathrm{t} \text { of (primary) pig iron production }\end{array}$ & Values for India taken from GMA $2018^{1}$ \\
\hline \multicolumn{3}{|c|}{ Secondary steel production (SSC) Electric Arc Furnace } \\
\hline Secondary steel production & $\begin{array}{l}0.002 \text { (low), } 0.032 \text { (intermediate) and } 0.2 \\
\text { (high) } \mathrm{g} / \mathrm{t} \text { of secondary steel produced }\end{array}$ & Default \\
\hline \multicolumn{3}{|c|}{ Non-ferrous metal production (NFMP) } \\
\hline Primary Copper & $\begin{array}{l}4.5 \text { (low), } 8.5 \text { (intermediate) and } 17.2 \text { (high) } \\
\mathrm{g} / \mathrm{t} \text { of copper produced (primary production) }\end{array}$ & Values for India taken from GMA $2018^{1}$ \\
\hline Primary Lead & $\begin{array}{l}2.7 \text { (low), } 10.8 \text { (intermediate) and } 21.6 \\
\text { (high) g/t of lead produced (primary } \\
\text { production) }\end{array}$ & Values for India taken from GMA $2018^{1}$ \\
\hline Primary Zinc & $\begin{array}{l}17.1 \text { (low), } 51.2 \text { (intermediate) and } 120 \\
\text { (high) } \mathrm{g} / \mathrm{t} \text { of zinc produced (primary } \\
\text { production) }\end{array}$ & 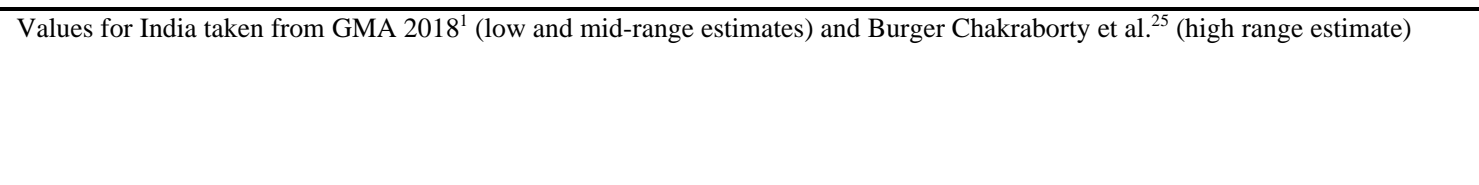 \\
\hline 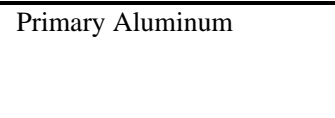 & $\begin{array}{l}.03 \text { (low), } 0.31 \text { (intermediate) and } 0.9 \\
\text { (high) } \mathrm{g} / \mathrm{t} \text { of aluminum produced }\end{array}$ & 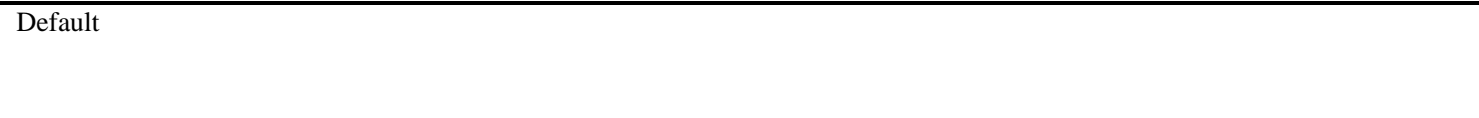 \\
\hline Large scale Gold & $55000 \mathrm{~g} / \mathrm{t}$ of gold produced & $\begin{array}{c}\text { Default } \\
\end{array}$ \\
\hline \multicolumn{3}{|l|}{ Other industry } \\
\hline Cement (excluding fuels) & $\begin{array}{l}0.048 \text { (low), } 0.124 \text { (intermediate) and } 0.2 \\
\text { (high) } \mathrm{g} / \mathrm{t} \text { cement }\end{array}$ & Values for India taken from GMA $2018^{1}$ \\
\hline Cement (Pet coke) & $\begin{array}{l}0.01 \text { (low), } 0.04 \text { (intermediate), } 0.37 \text { (high) } \\
\mathrm{g} / \mathrm{t} \text { petroleum coke }\end{array}$ & Default \\
\hline
\end{tabular}




\begin{tabular}{|c|c|c|}
\hline Oil Refining & $0.014716 \mathrm{~g} / \mathrm{t}$ crude oil refined & Value for India taken from GMA $2018^{1}$ \\
\hline \multicolumn{3}{|l|}{ Intentional use } \\
\hline $\begin{array}{l}\text { Chlor-alkali production } \\
\text { (mercury process) }\end{array}$ & $\begin{array}{l}3.75 \text { (low), } 10 \text { (intermediate), } 21.6 \text { (high) } \\
\text { g/t of Chlorine capacity }\end{array}$ & $\begin{array}{l}\text { Mid-range value for India taken from Global Mercury Assessment } 2013^{39} \text {; the high and low range values are assumed to be the same } \\
\text { as for Argentina, whose mid-range emission factor is the same as India's, due to lack of better information. }\end{array}$ \\
\hline $\begin{array}{l}\text { VCM Production (acetylene } \\
\text { process) }\end{array}$ & $\begin{array}{l}1 \text { (low), } 47 \text { (intermediate), } 61 \text { (high) } \mathrm{g} / \mathrm{t} \text { of } \\
\text { VCM capacity }\end{array}$ & Values are based on a study on VCM production in Russia and are taken from Burger Chakraborty et al. ${ }^{25}$ \\
\hline VCM Recycling & $\begin{array}{l}1 \text { (low), } 47 \text { (intermediate), } 61 \text { (high) } \mathrm{g} / \mathrm{t} \text { of } \\
\text { VCM capacity to calculate the recovered } \\
\text { catalyst. } \\
\text { Emission factor to air= } 0.05\end{array}$ & $\begin{array}{l}\text { Note: Half the mercury catalyst is assumed to be lost while the other half is assumed to be recovered. }{ }^{1,25} \\
\text { Default emission factor to air is obtained from GMA } 2018^{1} \text {. }\end{array}$ \\
\hline Dental sector & $\begin{array}{l}\text { Amount of } \mathrm{Hg} \text { used in each filling: } 0.6 \mathrm{~g} \\
\text { (low), } 0.75 \mathrm{~g} \text { (middle) }, 1 \mathrm{~g} \text { (high). }\end{array}$ & $\begin{array}{l}\text { Values are taken from a report by Toxics Link }{ }^{17} \text {. Low range estimate is based on statistical data of } \mathrm{Japan}^{43} \text { and high range estimate is } \\
\text { the reported average } \mathrm{Hg} \text { content of dental fillings }{ }^{44} \text {. Mid-range estimate is the average of low and high range estimates. }\end{array}$ \\
\hline Gold recovery from e-waste & $\begin{array}{l}3.5 \mathrm{~g} \text { of } \mathrm{Hg} \text { is assumed to be lost per } \mathrm{g} \text { of } \\
\text { gold recovered; factor of loss to air }=0.7\end{array}$ & Values are for India and are obtained from Burger Chakraborty et al. ${ }^{25}$ and a study on gold recovery processes in Bangalore, India ${ }^{45}$. \\
\hline \multicolumn{3}{|c|}{ Water and Waste ( $\mathrm{Hg}$ content of products) } \\
\hline $\begin{array}{l}\text { Compact Fluorescent Lamps } \\
\text { (Hg dosing per unit) }\end{array}$ & $\begin{array}{l}15 \mathrm{mg} \text { (low), } 20 \mathrm{mg} \text { (intermediate), } 21.21 \\
\mathrm{mg} \text { (high) }\end{array}$ & $\begin{array}{l}\text { Data is from Indian sources. Low and mid-range dosing obtained from ELCOMA }{ }^{46} \text {. High range estimate obtained from a study by } \\
\text { Toxics Link }{ }^{29} \text { which examined } 22 \text { samples of CFLs available in India. }\end{array}$ \\
\hline $\begin{array}{l}\text { Fluorescent Lamps (Hg } \\
\text { dosing per unit) }\end{array}$ & $\begin{array}{l}15 \mathrm{mg} \text { (low), } 60 \mathrm{mg} \text { (intermediate), } 64.12 \\
\mathrm{mg} \text { (high) }\end{array}$ & $\begin{array}{l}\text { Data is from Indian sources. Low and mid-range dosing obtained from ELCOMA }{ }^{46} . \text { High range estimate obtained from a study by } \\
\text { Toxics Link }{ }^{29} \text { which examined } 4 \text { samples of fluorescent lamps available in India. }\end{array}$ \\
\hline $\begin{array}{l}\text { Sphygmomanometers }(\mathrm{Hg} \\
\text { dosing per unit) }\end{array}$ & $20 \mathrm{~g}$ (low), $60 \mathrm{~g}$ (intermediate and high) & $\begin{array}{l}\text { Data is from Indian sources. Guidelines issues by } \mathrm{CPCB} \text { on proper management of } \mathrm{Hg} \text { containing waste generated from health care } \\
\text { facilities }{ }^{47} \text { estimate the typical } \mathrm{Hg} \text { content of sphygmomanometers as } 20-60 \mathrm{~g} \text { per unit. As per studies by Toxics } \text { Link }^{48,49} \text {, the average } \\
\mathrm{Hg} \text { contained in Sphygmomanometers in India is } 60 \mathrm{~g} \text {. }\end{array}$ \\
\hline $\begin{array}{l}\text { Thermometers (Hg dosing } \\
\text { per unit) }\end{array}$ & $0.6 \mathrm{~g}$ (low), $1 \mathrm{~g}$ (intermediate and high) & $\begin{array}{l}\text { Data is from Indian sources. A study by } \mathrm{CPCB}^{33} \text { estimates the } \mathrm{Hg} \text { content of thermometers as } 0.6-1 \mathrm{~g} \text { per unit. As per studies by } \\
\text { Toxics Link }{ }^{48,50} \text {, the average } \mathrm{Hg} \text { contained in thermometers in India is } 1 \mathrm{~g} \text {. }\end{array}$ \\
\hline Batteries (Hg dosing) & $\begin{array}{l}\text { Carbon-Zinc: } 3.8 \mathrm{mg} / \mathrm{kg} \text { (low), } 0.0005 \% \text { by } \\
\text { weight of battery (intermediate) } \\
\text { Alkaline: } 3.9 \mathrm{mg} / \mathrm{kg} \text { (low), } 0.0005 \% \text { by } \\
\text { weight of battery (intermediate) } \\
\text { Button cell: } 0.8 \% \text { by weight of cell (low } \\
\text { and intermediate) }\end{array}$ & $\begin{array}{l}\text { Data on Hg dosing of batteries in India is scarce. The following assumptions were made. } \\
\text { Low range estimate for dry cells: Recknagel et al. } .^{51} \text { tested samples of commercially available batteries (sizes D and AA) in Germany } \\
\text { and found the maximum } \mathrm{Hg} \text { content of Carbon-Zinc cells to be } 3.8 \mathrm{mg} / \mathrm{kg} \text {, and that of alkaline cells to be } 3.9 \mathrm{mg} / \mathrm{kg} \text {. These values are } \\
\text { considered for low range estimates in this study. The } \mathrm{Hg} \text { content of AAA cells are assumed to be the same as those of sizes D and } \\
\text { AA. } \\
\text { For the mid-range estimates, the maximum permissible Hg content per battery as per the Draft Battery Waste Management Rules } \\
(2020)^{52} \text { of the Ministry of Environment, Forest and Climate Change, Government of India, is considered. } \\
\text { Weights of Carbon-Zinc and alkaline dry cells (sizes D, AA and AAA) are obtained from specifications of Panasonic }{ }^{53} \text { batteries. } \\
\text { Weight of button cells is taken from Sathaiyan et al. }{ }^{37}\end{array}$ \\
\hline & \multicolumn{2}{|c|}{$\begin{array}{l}\text { The high range estimate of Hg emissions from Batteries is computed as per the methodology in GMA } 2018^{1} \text { report, by estimating India's share of Hg usage in this segment out of } \\
\text { South Asia's consumption. The consumption of Hg in batteries in South Asia in } 2004 \text { and } 2007 \text { are assumed to be the same as in } 2005 \text {, which is obtained from the Global Mercury } \\
\text { Assessment } 2008^{38} \text { report. The consumption of Hg in batteries in South Asia in } 2011 \text { is assumed to be the same as in 2010, which is obtained from the Global Mercury Assessment } \\
2013^{39} \text { report. The consumption of Hg in batteries in South Asia in } 2014 \text { is assumed to be the same as in } 2015 \text {, which is obtained from the GMA } 2018^{1} \text { report. India's share of Hg } \\
\text { consumption in batteries is estimated using its gross domestic product at purchasing power parity (GDP-PPP) for each year of the study. GDP-PPP data is taken from The World } \\
\text { Bank }^{19} \text {. }\end{array}$} \\
\hline $\begin{array}{l}\text { Estimating } \mathrm{Hg} \text { emissions to ai } \\
\text { Waste stream }\end{array}$ & from Hg-containing products entering the & $\begin{array}{l}\text { The waste stream characterization is obtained from the GMA } 2018^{1} \text { report which encompasses: } \\
\text { - Initial distribution factors for Hg-containing products } \\
\text { - Waste distribution factors, and specific distribution factors for controlled and uncontrolled waste incineration, and for } \\
\text { managed and unmanaged waste landfilling } \\
\text { - Emission factors for a) breakage/release of Hg containing products during use, b) waste recycling, c) controlled waste } \\
\text { incineration, d) uncontrolled waste incineration, e) managed landfilling of waste, and f) unmanaged landfill of waste }\end{array}$ \\
\hline
\end{tabular}




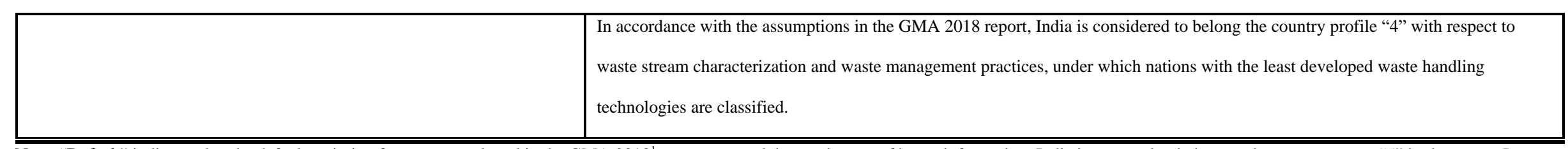

Note: "Default" indicates that the default emission factors as employed in the GMA $2018^{1}$ report are used due to absence of better information. India is assumed to belong to the country group " 5 " in the report. Low and high range estimates of emission factors for the categories where specific data is not available have been calculated as per methods outlined in GMA $2018^{1}$ report.

Table S4. Technology profiles of emission reduction in each activity (percentage of reduction efficiency of applied air pollution control mechanism and percentage degree of application to the total unabated emissions)

\begin{tabular}{|c|c|c|c|}
\hline & Reduction efficiency & Degree of application & References \\
\hline \multicolumn{3}{|l|}{ Coal- Power plants } & \multirow{31}{*}{$\begin{array}{l}\text { The technologies employed for pollution control in the activities listed here } \\
\text { and the associated degree of application to emissions, as well as their } \mathrm{Hg} \\
\text { reduction efficiencies are as per the assumptions in the GMA } 2018^{1} \text { report. } \\
\text { "Default" technology profiles as applied in the GMA } 2018^{1} \text { report are used } \\
\text { for activities where there is a lack of better information. India is assumed to } \\
\text { belong to the country group "5" in the report. For intentional use sectors } \\
\text { other than Chlor-alkali production, any abatement of Hg emissions is not } \\
\text { considered due to unavailability of sufficient data. }\end{array}$} \\
\hline $\begin{array}{l}\text { Electrostatic precipitator (some plants use coal washing or other } \\
\text { pollution control mechanisms) }\end{array}$ & $42 \%$ & $100 \%$ & \\
\hline \multicolumn{3}{|l|}{ Oil- Power plants, Industry } & \\
\hline None & $0 \%$ & $100 \%$ & \\
\hline \multicolumn{3}{|l|}{ Natural Gas- Power plants, Industry } & \\
\hline None & $0 \%$ & $100 \%$ & \\
\hline \multicolumn{3}{|l|}{ Cement Industry } & \\
\hline Uncontrolled & $0 \%$ & $1 \%$ & \\
\hline Electrostatic precipitator & $25 \%$ & $99 \%$ & \\
\hline \multicolumn{3}{|l|}{ Coal- Industry } & \\
\hline None & $0 \%$ & $75 \%$ & \\
\hline $\begin{array}{l}\text { For particulate matter: electrostatic precipitator / particle scrubber / } \\
\text { cyclone separators }\end{array}$ & $5 \%$ & $25 \%$ & \\
\hline \multicolumn{3}{|l|}{ Biomass burning- Industry } & \\
\hline None & $0 \%$ & $75 \%$ & \\
\hline $\begin{array}{l}\text { For particulate matter: electrostatic precipitator / particle scrubber / } \\
\text { cyclone separators }\end{array}$ & $5 \%$ & $25 \%$ & \\
\hline \multicolumn{3}{|l|}{ Biomass burning- Power plants } & \\
\hline None & $0 \%$ & $100 \%$ & \\
\hline \multicolumn{3}{|l|}{ Iron and Steel (Primary production) } & \\
\hline None & $0 \%$ & $100 \%$ & \\
\hline \multicolumn{3}{|l|}{ Secondary steel production } & \\
\hline None & $0 \%$ & $50 \%$ & \\
\hline $\begin{array}{l}\text { For particulate matter: electrostatic precipitator / particle scrubber / } \\
\text { cyclone separators }\end{array}$ & $10 \%$ & $50 \%$ & \\
\hline \multicolumn{3}{|l|}{ Primary Copper, Primary Lead, Primary Zinc } & \\
\hline None or simple particle filters & $0 \%$ & $10 \%$ & \\
\hline Particle control, wet gas cleaning, and integrated acid plant & $95 \%$ & $90 \%$ & \\
\hline \multicolumn{3}{|l|}{ Primary Aluminum, Large scale Gold } & \\
\hline None & $0 \%$ & $100 \%$ & \\
\hline \multicolumn{3}{|l|}{ Oil Refining } & \\
\hline None & $0 \%$ & $100 \%$ & \\
\hline \multicolumn{3}{|l|}{ Chlor-alkali production (mercury process) } & \\
\hline Best environmental practices & $50 \%$ & $100 \%$ & \\
\hline
\end{tabular}

Note: Technology profiles for estimating low and high range estimates of emissions have been calculated as per methods outlined in GMA $2018^{\underline{1}}$ report.

\section{S2. Hg emissions inventory of India}

The atmospheric $\mathrm{Hg}$ emissions in India due to anthropogenic activities were $84 \mathrm{t}$ in 2004, 108t in 2007, 159t in 2011, and 189t in 2014 . The $\mathrm{Hg}$ emission inventories of 2004, 2007, 2011 and 2014 for India can be viewed in Table S8 and the production-based Hg emissions of India's economic 
sectors are shown in Table S9. Figure S1 shows the trend of Hg emissions from some top emitting sectors during the four years. The results for the 65 economic sectors in the GTAP MRIO tables are grouped into 11 aggregate sectors as shown in Table S6 for the purpose of the figure.

The Electricity sector was the top direct emitter during each year of the study. From the annual energy consumption data obtained from IEA, we find that the consumption of coal in power plants had increased during each interval, from 325,631 kt in 2004 to $394,803 \mathrm{kt}$ in 2007 , to 470,059 $\mathrm{kt}$ in 2011 and $608,550 \mathrm{kt}$ of coal in 2014. Considering an emission factor of $0.14 \mathrm{~g} / \mathrm{t}^{40}$ for coal combustion in power plants, the Hg emissions occurring due to combustion of coal in Indian power plants amounts to 26t, 32t, 38t, and 49t in 2004, 2007, 2011 and 2014, respectively, after accounting for pollution control mechanisms. Combustion of other fuels in power plants (oil, natural gas and primary solid biomass) collectively account for less than 1t of $\mathrm{Hg}$ emissions from the Electricity sector in each year.

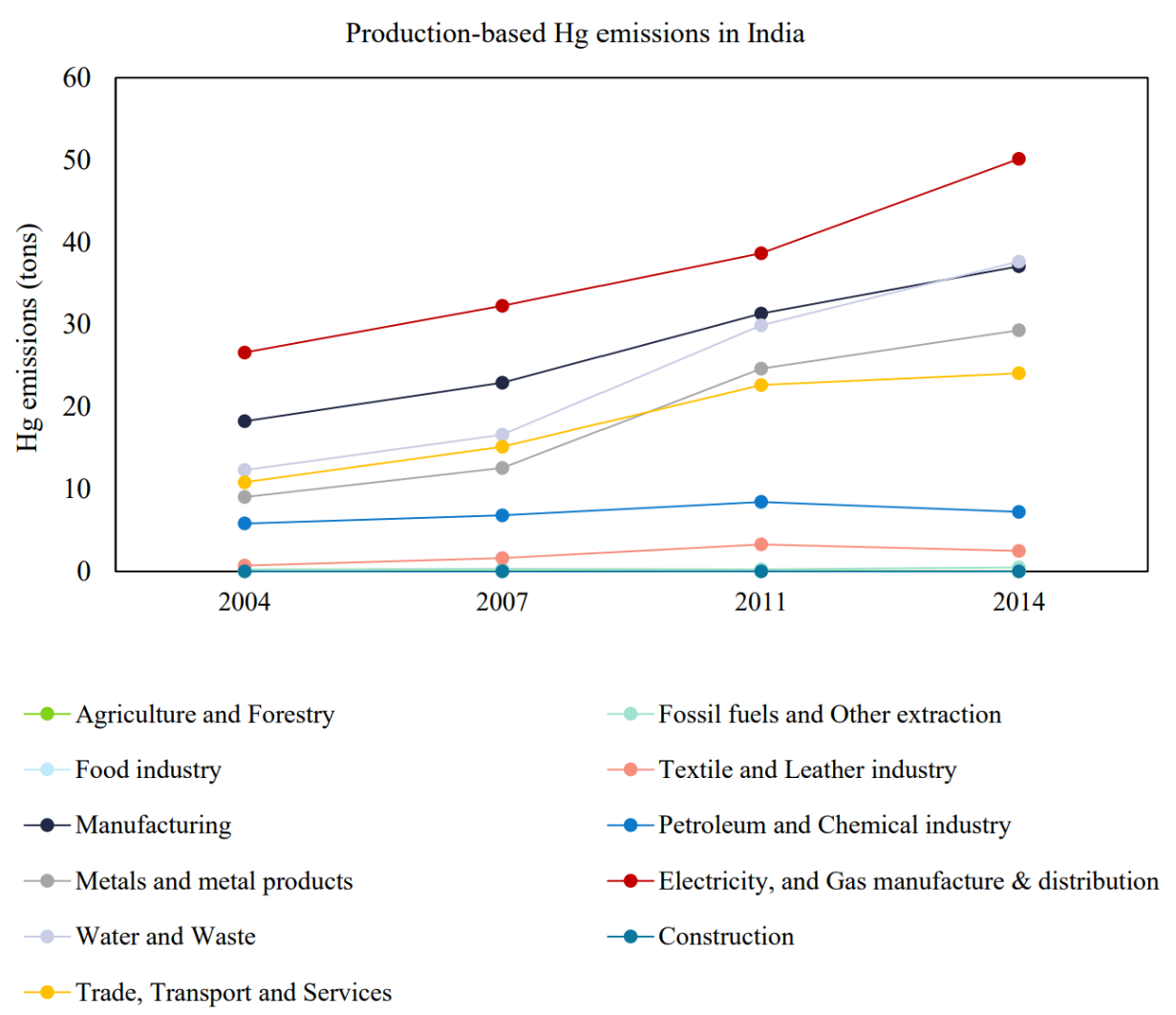

Figure S1. Production-based Hg emissions of India during 2004, 2007, 2011 and 2014.

The total coal consumed in industrial sectors (Ferrous metals sector, Non-ferrous metals sector, Mineral products nec sector mainly comprising of the cement industry, and other industries) was $66,131 \mathrm{kt}$ in $2004,86,565 \mathrm{kt}$ in $2007,151,540 \mathrm{kt}$ in 2011, and 172,115 kt in 2014 . The coal consumption in the industrial sectors contributed to about 16t, 21t, 37t, and 42t of $\mathrm{Hg}$ emissions in the four years, respectively, after accounting for pollution control mechanisms. The largest contributors in this segment are the Ferrous metals sector and the Mineral products nec sector. As is apparent from Table S8, Hg emissions from the Mineral products nec sector (mapped to cement industries) occur to a larger extent due to the $\mathrm{Hg}$ content of raw materials as compared to the coal combustion related emissions. In case of the Ferrous metals sector, the emissions from coal combustion are higher than the emissions due to the Hg content of raw materials.

The Water and Waste sector was responsible for 12t, 17t, 30t and 38t of Hg emissions during 2004, 2007, 2011 and 2014, respectively. The hike in import of sphygmomanometers ${ }^{32}$ can explain the sharp increase in the estimated Hg emissions of this sector between 2007 and 2011 . There is an additional category called "other use" in the estimation of emissions from wastes in the GMA 2018 report. This category includes pesticides, laboratory chemicals, pharmaceuticals, cosmetics etc. The GMA 2018 report estimates $\mathrm{Hg}$ emissions in India from this category using the value of Hg consumption for "other use" in South Asia. However, this category is not included in the present study due to insufficient information on the activity rates and the emission factor to air, as well as the ban of $\mathrm{Hg}$ containing pesticides in India. The use of Methoxy Ethyl Mercury Chloride (MEMC) was earlier allowed for the seed treatment of potatoes and sugarcane ${ }^{25}$ before being completely banned in $2018 .{ }^{54}$ However, the 
assumption of a negligible transfer coefficient of $\mathrm{Hg}$ from pesticides to air in the study by Burger Chakraborty et al. is also adopted in this study. With regard to cosmetics, while domestic skin-care products and skin lightening creams are found to have low Hg content, imported fairness creams are reported to have substantially high levels of $\mathrm{Hg}$ (about 3-32 $\mathrm{kg} \mathrm{Hg}$ per ton). ${ }^{55}$ However, due to absence of sufficient data on the market share of imported fairness creams, their entry into the waste stream, as well as the transfer potential to air, this category is not included in present study.

The Hg emissions occurring from the dental sector in India is accounted for in the Human health and social work activities sector (belongs to the Trade, Transport and Services sectors group). The estimated Hg emissions from the dental sector is estimated to be 5t, 9t, 14t, and 15t, in 2004, 2007, 2011 and 2014, respectively. The increase in emissions of this sector was especially significant between 2004 and 2007 , and between 2007 and 2011, as compared to the change between 2011 and 2014. This is because of the higher increase in population between the former two pairs of years $^{19}$, as well as the higher increase in the dentist to population ratio between the former two pairs of years ${ }^{20,21,22}$. These changes affect the estimates of the number of dental restorations performed in a year and the total amount of $\mathrm{Hg}$ used in restorations.

With regard to the Metals nec sector (belongs to the Metals and metal products sectors group), in the estimation of Hg emissions by Burger Chakraborty et al. ${ }^{25}$, zinc production was found to be a significant source of $\mathrm{Hg}$ emissions along with coal power plants. Due to absence of better information, their study assumed that pollution abatement in metal production facilities was similar to coal power plants. According to this assumption, only $11 \%$ of the $\mathrm{Hg}$ in emissions from metal production facilities was captured using electrostatic precipitators. However, the present study uses the "default" technology profile for pollution abatement applicable to country group "5" in the GMA 2018 report for all non-ferrous metal production. As per this assumption, about $86 \%$ of $\mathrm{Hg}$ from the emissions is captured due to the use of particle control, wet gas cleaning and acid plant in copper, lead and zinc production facilities. However, there is also a discrepancy with the Hg emissions estimate of the GMA 2018 report. This is due to the use of "default" Hg emission factor used for estimating Hg emissions from Indian zinc production in the report, whereas the India-specific Hg emission factor, also provided in the same report, is used in this study. Therefore, there is a relatively high level of uncertainty associated with the $\mathrm{Hg}$ emissions from the Metals nec sector. The range of $\mathrm{Hg}$ emissions values are provided in Table S9.

Additionally, according to the estimates in the GMA 2018 report, about 5t (2-7t) per year of $\mathrm{Hg}$ is emitted from Artisanal and Small-Scale Gold Mining (ASGM) activities which intentionally use Hg. These emissions which could be mapped to the "Other Extraction" sector, are not considered in further MRIO analyses. There is insufficient information to estimate $\mathrm{Hg}$ emissions from ore mining activities. ${ }^{1}$ Allocating only the ASGM Hg emissions to this sector, therefore, results in erroneous consumption-based allocation of responsibility to some foreign sectors.

\section{S3. Discussion on production-based Hg emissions of top sectors}

(1) Electricity. In 2004, the total installed thermal power capacity was $78 \mathrm{GW}$, which had more than doubled to $168 \mathrm{GW}$ by $2014 .{ }^{56} \mathrm{The} \mathrm{Hg}$ emissions of the Electricity sector increased almost twofold during this period. It was only in 2015 that an amendment was made to the Environment (Protection) rules $^{57}$, which until then had prescribed emission limits for particulate matter (PM) from thermal power plants, to include emission limits for $\mathrm{Hg}\left(0.03 \mathrm{mg} / \mathrm{Nm}^{3}\right)$ along with limits for $\mathrm{SO}_{2}$ and $\mathrm{NO}_{x}$. The implementation of these rules, however, has not been successful due to several factors such as lack of experience in large scale installation of emissions control systems, issues with availability and supply of technology, the required shut down of power supply and associated revenue losses, and uncertainty regarding regulatory treatment of power tariffs among producers. ${ }^{58,59}$ The latest amendment ${ }^{60}$ has further modified and extended the deadlines for compliance to these limits according to plant locations and vicinity to densely populated areas. The Thermal Projects Renovation \& Modernisation Division of CEA has planned a phased implementation of flue gas desulphurization (FGD) and upgradation of electrostatic precipitators (ESP) for controlling $\mathrm{SO}_{2}$ and $\mathrm{PM}$ emissions, respectively ${ }^{61}$ 
However, $\mathrm{Hg}$-specific emissions reduction guidelines have not been provided. A detailed analysis of the $\mathrm{Hg}$ emissions reduction potential as a cobenefit of flue gas desulphurization (FGD), upgradation of electrostatic precipitators (ESP), and possible NOx specific technology recommendations such as Selective Catalytic Reduction (SCR), is required. Further, a feasibility study on other commercially available Hg-specific emissions control technologies such as Activated Carbon Injection (ACI) and ACI with Fabric Filter (FF) ${ }^{62,63}$ is recommended, taking into account the potential $\mathrm{Hg}$ emissions reduction of the already planned technologies of FGD and ESP. The guidelines for the renovation and modernization of thermal power plants may then be updated to include $\mathrm{Hg}$-specific measures. Thermal power plants are also covered under the Perform, Achieve and Trade scheme ${ }^{64}$ of the Bureau of Energy Efficiency which sets target specific energy consumption levels for designated consumers. The thermal power category had surpassed its energy efficiency targets in PAT cycle II ${ }^{65}$. Increase in energy efficiency in this category can check future $\mathrm{Hg}$ emission increases due to the requirements of lower quantity and better quality of fuel.

(2) Water and Waste. As per the Article 4 of the Minamata Convention, the manufacture, export and import of most kinds of Hg containing batteries, switches and relays, lamps, cosmetics, pesticides and other chemicals, measuring devices including thermometers and sphygmomanometers, has been prohibited after 2020. However, India, which became party to the Convention in June, 2018, had applied for exemptions ${ }^{66}$ with regard to the deadline for compliance, and proposed 2025 as the deadline. The reasons cited were the lack of information on the manufacturing of $\mathrm{Hg}$ added products in India, and the lack of information on the quantity of $\mathrm{Hg}$ present in the products. The notice of the registration of exemptions further states that a detailed inventory of manufacturing of Hg-added products in India will be compiled, and technoeconomically feasible alternatives to these products would be identified, post which a phase out plan will be designed and implemented. This study, along with previous studies on India's Hg emissions, ${ }^{3,25}$ can serve as a model for compiling an inventory for more recent years, however, a detailed investigation of the market and traders for $\mathrm{Hg}$ containing products is urgently required. Until the phase-out is achieved, waste disposal and management is a priority area for controlling the $\mathrm{Hg}$ emissions in this sector. Improper or no segregation of waste at the source leads to domestic wastes, medical wastes, as well as hazardous wastes being collectively deposited at open dumpsites. This waste is burnt in an uncontrolled manner to reduce its quantity. ${ }^{67}$ Landfill mining, constructing sanitary engineered landfills, and using waste as a resource in waste-to-energy plants are some recommended measures for dealing with the waste management problem in India. ${ }^{68}$ The Solid Waste Management (SWM) Rules, $2016^{69}$ promotes the use of refuse derived fuel (RDF) in industrial units using fuel. Cement plants in India have started co-processing wastes for their fuel requirements and are also suitable for the disposal of hazardous wastes. ${ }^{70}$

(3) Mineral Products nec. The Indian cement sector is considered as one amongst the most energy efficient and sustainable in the world. ${ }^{70}$ It had surpassed its energy efficiency targets by more than $80 \%$ in PAT (Perform, Achieve and Trade) cycle $\mathrm{I}^{71}$ and more than $40 \%$ in PAT cycle II ${ }^{65}$. The sector has also been able to reduce its $\mathrm{CO}_{2}$ emissions intensity from the baseline emissions intensity of 2010 due to sector-wide sustainabilityfocused initiatives such as an increase in the share of alternative fuel use, blended cement production, and reduction in clinker factor. ${ }^{70}$ However, Hg emissions have not been at the forefront of the sector's sustainability goals. Between 2004-2014, the Hg emissions of this sector had increased more than twofold. $\mathrm{Hg}$ emissions from raw materials in cement manufacturing industries need to be addressed through regulatory instruments as well as voluntary initiatives, as seen in the case of the sector's energy conservation measures ${ }^{72}$. Standards for emissions of particulate matter, $\mathrm{SO}_{2}$, and $\mathrm{NO}_{\mathrm{x}}$ from cement industries have been established in the Environment (Protection) Rules ${ }^{73,74}$, however standards for Hg emissions have been included only for cement plants with co-processing of wastes $\left(0.05 \mathrm{mg} / \mathrm{Nm}^{3}\right)^{75} . \mathrm{Hg}$ emission standards along with compliance deadlines must be established for cement plants across the country. Most Indian cement plants are assumed to be equipped with ESPs through which only about $25 \%$ of $\mathrm{Hg}$ emissions abatement is estimated to be achieved. ${ }^{1}$ The Minamata Convention ${ }^{76}$ requires application of best available techniques and best environmental practices (BAT/BEP) for $\mathrm{Hg}$ emissions control in new or substantially modified establishments, and recommends their application in existing facilities as well. The guidance document adopted by the Conference of the Parties ${ }^{77}$ recommends primary practices such as the use of 
low Hg input materials (including alternative fuels), selective mining of raw materials and fuels, and locating the new production facilities near low Hg limestone quarries. Secondary techniques such as dust shuttling and the combined use of dust shuttling and sorbent injection, as well as multi-pollutant control techniques (wet scrubber for flue gas desulfurization, selective catalytic reduction, etc.) are recommended after careful consideration of $\mathrm{Hg}$ emissions removal requirement and cross-media effects. The potential for $\mathrm{Hg}$ emissions reduction through various technology options must be studied along with their economic feasibility. Policy support mechanisms from the government must be identified and an implementation plan must be drawn for incorporating BATs/BEPs in cement plants across the country.

(4) Metals nec. The guidance document adopted by the Conference of the Parties ${ }^{77}$ comprehensively discusses the available and emerging $\mathrm{Hg}$ emissions abatement technologies in non-ferrous metal production. These are both specific to $\mathrm{Hg}$ emissions such as Boliden Norzink process, Selenium filter, sulfur-impregnated activated carbon, etc. ${ }^{77}$ as well as common emissions abatement technologies that control Hg emissions as a co-benefit. The document recommends the use of site-specific data to determine the best technology or combination of technologies for emissions abatement at production facilities.

(5) Ferrous metals. The direct Hg emissions of the Ferrous metals sector increased significantly during 2004-2014 alongside the expansion of the sector and the corresponding coal combustion. Information on emissions abatement in the Indian Ferrous metals sector is insufficient. Following the GMA $2018^{1}$ report, it is assumed that there is no abatement of $\mathrm{Hg}$ from primary iron production, and only $5 \%$ of abatement in secondary steel production. Emission standards for the Ferrous metals sector ${ }^{78,79}$ do not specify limits for $\mathrm{Hg}$ emissions. It is recommended that emission standards be updated with $\mathrm{Hg}$ emissions limits along with a sector-wide implementation plan and guidelines for emissions control, as is being done in the case of thermal power plants. Iron and Steel industries are covered under the PAT scheme ${ }^{64}$. The sector has achieved additional savings beyond the targeted energy consumption reductions in the first two PAT cycles. ${ }^{65,71}$ The targets maybe reviewed and modified over time as less energyintensive production processes become commercially available. Additionally, the shares of primary and secondary steel production are nearly equal at present. The Draft National Resource Efficiency Policy ${ }^{80}$, however, recognizing the resource intensiveness of primary steel production, calls for setting up of modern and efficient scrap processing facilities near scrap consuming centers. Moreover, it emphasizes the need to recycle domestic steel and reduce the reliance on scrap imports. Primary steel production is more energy intensive than secondary steel production due to the additional energy required to reduce iron ore to iron using reducing agents. ${ }^{81}$ Therefore, higher levels of recycling as compared to production of primary steel has the potential to reduce $\mathrm{Hg}$ emissions of this sector. The Steel Scrap Recycling Policy ${ }^{82}$ aims to ensure the availability of quality scrap to the steel industry so that high grade steel may be produced for use in downstream sectors. Furthermore, the innovation and uptake of alternative technologies such as HIsarna ${ }^{83}$ and hydrogen-based steel production ${ }^{84}$ may be encouraged depending upon the viability and emissions reduction potentials. The HIsarna technology claims to greatly reduce emissions of hydrogen, sulfur dioxide and nitrogen oxides, apart from the reduction of energy consumption and $\mathrm{CO}_{2}$ emissions; combined with Carbon Capture, Utilization and Storage (CCUS), the emissions are expected to be completely controlled. $\mathrm{Hg}$ emissions must also be a point of focus in such emerging technological innovations.

(6) Human health and social work activities. In recent years, there is a preferential shift among the Indian population towards composite fillings due to its aesthetic appeal, and moreover, several hospitals and clinics in India have shifted to composite fillings due to increased awareness regarding the toxicity of $\mathrm{Hg}$. However, there are concerns regarding the shorter life of alternate fillings and other clinical limitations. ${ }^{85}$ The Minamata Convention requires the phase out of $\mathrm{Hg}$ use in dental restorations while also identifying safe, effective and economical alternatives.

(7) Chemical Products. Contrary to the general trend of increasing $\mathrm{Hg}$ emissions over the years, the $\mathrm{Hg}$ emissions of the Chemical products sector had declined during 2004-2014. The Hg emissions in this sector are primarily from the chlor-alkali industry and the vinyl chloride monomer (VCM) industry. Chlor-alkali industries in India which were initially based on the mercury cell technology, shifted to the membrane cell technology 
mainly owing to environmental concerns and economic advantages. ${ }^{86}$ The chlor-alkali industry was a partner of the Charter on Corporate Responsibility for Environmental Protection (CREP), 2003 ${ }^{87}$. CREP 2003 was a collaborative initiative of the Indian government and industry to shift from regulatory enforcement of pollution control norms to voluntary compliance by the industry, with the objective of controlling pollution and enhancing the quality of environment. ${ }^{88}$ Per the charter, chlor-alkali plants were to switch over to membrane cell technology from the mercury cell technology. India had phased out its mercury-cell chlor-alkali facilities from 16 plants in 2002, to 2 in $2014\left(0\right.$ in 2015) ${ }^{14}$, causing the $\mathrm{Hg}$ emissions from the Chemical products sector to decline.

\section{S4. Sensitivity analysis}

Table S5. Absolute and relative sensitivities of the total $\mathrm{Hg}$ emissions to emission abatement technology profiles of selected activities. Y is the dependent variable i.e., total $\mathrm{Hg}$ emissions in tons; $\mathrm{X}$ is the parameter i.e., emission abatement technology profile in \% (Reduction efficiency of the air pollution control technology used for an activity $\times$ Degree of application of the technology to the total emissions from the activity).

\begin{tabular}{|c|c|c|c|c|c|c|c|c|c|c|c|c|c|c|c|c|}
\hline \multirow{3}{*}{$\begin{array}{l}\text { Parameters: Technology } \\
\text { profiles of following } \\
\text { activities }\end{array}$} & \multicolumn{4}{|c|}{ Absolute sensitivity } & \multicolumn{4}{|c|}{ Relative sensitivity } & \multicolumn{4}{|c|}{ Absolute sensitivity per $100 \%$} & \multicolumn{4}{|c|}{ Relative sensitivity per $100 \%$} \\
\hline & \multicolumn{4}{|c|}{$\Delta \mathrm{Y} / \Delta \mathrm{X}$} & \multicolumn{4}{|c|}{$\% \Delta \mathrm{Y} / \Delta \mathrm{X}$} & \multicolumn{4}{|c|}{$\Delta \mathrm{Y} / \% \Delta \mathrm{X}$} & \multicolumn{4}{|c|}{$\% \Delta \mathrm{Y} / \% \Delta \mathrm{X}$} \\
\hline & 2004 & 2007 & 2011 & 2014 & 2004 & 2007 & 2011 & 2014 & 2004 & 2007 & 2011 & 2014 & 2004 & 2007 & 2011 & 2014 \\
\hline Coal combustion in power & & & & & & & & & & & & & & & & \\
\hline plants & -45.59 & -55.27 & -65.81 & -85.20 & -54.36 & -51.00 & -41.33 & -45.20 & -0.19 & -0.23 & -0.28 & -0.36 & -0.23 & -0.21 & -0.17 & -0.19 \\
\hline Zinc production & -12.21 & -22.06 & -40.12 & -37.53 & -14.56 & -20.35 & -25.20 & -19.91 & -0.10 & -0.19 & -0.34 & -0.32 & -0.12 & -0.17 & -0.22 & -0.17 \\
\hline Cement production & -22.00 & -27.51 & -37.72 & -46.20 & -26.24 & -25.38 & -23.69 & -24.51 & -0.05 & -0.07 & -0.09 & -0.11 & -0.06 & -0.06 & -0.06 & -0.06 \\
\hline Copper production & -3.41 & -5.95 & -5.70 & -6.51 & -4.06 & -5.49 & -3.58 & -3.45 & -0.03 & -0.05 & -0.05 & -0.06 & -0.03 & -0.05 & -0.03 & -0.03 \\
\hline $\begin{array}{l}\text { Primary iron and steel } \\
\text { production }\end{array}$ & -1.70 & -2.00 & -2.67 & -3.45 & -2.02 & -1.85 & -1.68 & -1.83 & -0.02 & -0.02 & -0.03 & -0.03 & -0.02 & -0.02 & -0.02 & -0.02 \\
\hline $\begin{array}{l}\text { Combustion of Hard Coal } \\
\text { in industries (except } \\
\text { cement) }\end{array}$ & -11.36 & -15.97 & -32.08 & -34.84 & -13.55 & -14.74 & -20.15 & -18.48 & -0.01 & -0.01 & -0.02 & -0.02 & -0.01 & -0.01 & -0.01 & -0.01 \\
\hline Chlor-alkali industry & -4.90 & -3.08 & -0.95 & -0.42 & -5.84 & -2.84 & -0.60 & -0.22 & -0.02 & -0.02 & 0.00 & 0.00 & -0.03 & -0.01 & 0.00 & 0.00 \\
\hline $\begin{array}{l}\text { Wastes associated with } \\
\text { mercury-added products } \\
\text { (sensitivity to total Hg } \\
\text { emission factor) }\end{array}$ & 53.43 & 71.98 & 129.79 & 163.27 & 63.72 & 66.41 & 81.51 & 86.62 & 0.12 & 0.17 & 0.30 & 0.37 & 0.15 & 0.15 & 0.19 & 0.20 \\
\hline
\end{tabular}

\section{S5. Sample EE-MRIO calculations}

There are 9165 nation sectors in the GTAP database. The satellite account (h) in this study is a row vector with Hg emissions values present only for Indian sectors, and direct emissions of all other nation-sectors are 0 . India is the $22^{\text {nd }}$ nation in the database, therefore the $\mathrm{Hg}$ emissions of Indian sectors are present in the positions 1366 to 1430 of the satellite account row vector i.e., $\mathrm{h}_{1,1366}$ to $\mathrm{h}_{1,1430}$. The column vector $\mathrm{x}$ denotes the total output of nation-sectors in millions of U.S. dollars. A row vector q of $\mathrm{Hg}$ emissions intensities (Hg emissions from each nation-sector per million USD output) is calculated using equation (1).

$$
q=h(\hat{x})^{-1}
$$

The hat ${ }^{\wedge}$ means diagonalizing the vector. As with h, only positions 1366 to 1430 in the row vector q have non-zero values. Consider the $46^{\text {th }}$ sector, Electricity. India-Electricity is present at the position 1411 in $\mathrm{h}$ and $\mathrm{x}$, i.e., $\mathrm{h}_{1,1411}$ and $\mathrm{x}_{1411,1}$. In $\hat{x}$, India-Electricity is present at $\hat{x}_{1411,1411}$. $\mathrm{h}_{1,1411}$ for 2014 is $50.13 \mathrm{t}$, and $\hat{x}_{1411,1411}$ for 2014 is 217316.78 million USD. $\mathrm{q}_{1,1411}$ is therefore, $0.00023 \mathrm{t} /$ million USD. 


\section{Demand-side analysis:}

The structure of the direct input coefficient matrix, A, is as shown in equation (2). The Leontief inverse is calculated as shown in equation (3).

$$
A=\left[\begin{array}{ccccc}
a_{11} & \cdots & a_{1 j} & \cdots & a_{1 n} \\
\vdots & \ddots & \vdots & \ddots & \vdots \\
a_{i 1} & \cdots & a_{i j} & \cdots & a_{i n} \\
\vdots & \ddots & \vdots & \ddots & \ddots \\
a_{n 1} & \cdots & a_{n j} & \cdots & a_{n n}
\end{array}\right]
$$

The Leontief inverse is calculated as,

$$
L=(I-A)^{-1}=\left(\left[\begin{array}{ccccc}
1 & \cdots & 0 & \cdots & 0 \\
\vdots & \ddots & \vdots & \ddots & \vdots \\
0 & \cdots & 1 & \cdots & 0 \\
\vdots & \ddots & \vdots & \ddots & \ddots \\
0 & \cdots & 0 & \cdots & 1
\end{array}\right]-\left[\begin{array}{ccccc}
a_{11} & \cdots & a_{1 j} & \cdots & a_{1 n} \\
\vdots & \ddots & \vdots & \ddots & \vdots \\
a_{i 1} & \cdots & a_{i j} & \cdots & a_{i n} \\
\vdots & \ddots & \vdots & \ddots & \ddots \\
a_{n 1} & \cdots & a_{n j} & \cdots & a_{n n}
\end{array}\right]\right)^{-1}
$$

and may be represented as shown in equation (4),

$$
L=\left[\begin{array}{ccccc}
l_{11} & \cdots & l_{1 j} & \cdots & l_{1 n} \\
\vdots & \ddots & \vdots & \ddots & \vdots \\
l_{i 1} & \cdots & l_{i j} & \cdots & l_{i n} \\
\vdots & \ddots & \vdots & \ddots & \ddots \\
l_{n 1} & \cdots & l_{n j} & \cdots & l_{n n}
\end{array}\right]
$$

The column vector $\mathrm{y}$, which contains the final demand on all the nation-sectors is obtained from the GTAP tables. Consider that we are interested in estimating the $\mathrm{Hg}$ emissions occurring in India due to the final demand of Australia, which is the first nation. Let the final demand column vector of Australia be yaus. The Hg emissions occurring in India due to Australia's final demand can be calculated by equation (5).

$$
c_{\text {aus }}=q * \mathbf{L} * \hat{y}_{\text {aus }}
$$

Rows 1366 to 1430 of L contain the values of direct and indirect inputs from Indian sectors required to satisfy unitary final demand of each nationsector (columns 1 to 9165). When q is multiplied with $\mathrm{L}$, a 1x9165 row vector is obtained, which contains the direct and indirect Hg emissions occurring in India per unit output of each nation-sector. When this product is further multiplied with $\hat{y}_{\text {aus }}$, a $1 \mathrm{x} 9165$ row vector containing the direct and indirect $\mathrm{Hg}$ emissions occurring in India due to the final demand of Australia on each of the 9165 nation-sectors is obtained. Similarly, the $\mathrm{Hg}$ emissions occurring in India due to each nation's final demand ( $\mathrm{c}_{\text {usa, }} \mathrm{c}_{\text {china, }}$ etc.) is calculated.

Consider that we are interested in knowing the Hg emissions in India due to the final demand of the United States of America (USA) on its Construction sector. USA is the $28^{\text {th }}$ nation and Construction is the $49^{\text {th }}$ sector in the GTAP tables. Therefore, USA-Construction is at the position

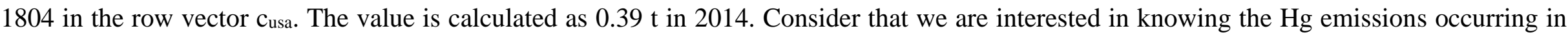
India due to the final demand of USA from the global construction sector, i.e., the construction sectors of all nations. In cusa, the Construction sectors of each nation can be isolated and summed to obtain this value $(0.39 \mathrm{t}$ in 2014$)$.

\section{Supply-side analysis:}

The structure of the direct output coefficient matrix, B, is as shown in equation (6).

$$
B=\left[\begin{array}{ccccc}
b_{11} & \cdots & b_{1 j} & \cdots & b_{1 n} \\
\vdots & \ddots & \vdots & \ddots & \vdots \\
b_{i 1} & \cdots & b_{i j} & \cdots & b_{i n} \\
\vdots & \ddots & \vdots & \ddots & \ddots \\
b_{n 1} & \cdots & b_{n j} & \cdots & b_{n n}
\end{array}\right]
$$


The Ghosh inverse matrix, G, is calculated as shown in equation (7),

$$
G=(I-B)^{-1}=\left(\left[\begin{array}{ccccc}
1 & \cdots & 0 & \cdots & 0 \\
\vdots & \ddots & \vdots & \ddots & \vdots \\
0 & \cdots & 1 & \cdots & 0 \\
\vdots & \ddots & \vdots & \ddots & \ddots \\
0 & \cdots & 0 & \cdots & 1
\end{array}\right]-\left[\begin{array}{ccccc}
b_{11} & \cdots & b_{1 j} & \cdots & b_{1 n} \\
\vdots & \ddots & \vdots & \ddots & \vdots \\
b_{i 1} & \cdots & b_{i j} & \cdots & b_{i n} \\
\vdots & \ddots & \vdots & \ddots & \ddots \\
b_{n 1} & \cdots & b_{n j} & \cdots & b_{n n}
\end{array}\right]\right)^{-1}
$$

and may be represented as shown in equation (8).

$$
G=\left[\begin{array}{ccccc}
g_{11} & \cdots & g_{1 j} & \cdots & g_{1 n} \\
\vdots & \ddots & \vdots & \ddots & \vdots \\
g_{i 1} & \cdots & g_{i j} & \cdots & g_{i n} \\
\vdots & \ddots & \vdots & \ddots & \ddots \\
g_{n 1} & \cdots & g_{n j} & \cdots & g_{n n}
\end{array}\right]
$$

The income-based $\mathrm{Hg}$ emissions of all nation sectors are calculated using equation (9).

$$
s=\hat{v} * \mathbf{G} * q^{\prime}
$$

The row vector $v$, which contains the primary inputs of all nation-sectors is obtained from the GTAP tables. The element $\mathrm{g}_{\mathrm{ij}}$ indicates the value of production, direct and indirect, enabled in sector $\mathrm{j}$ per unit of primary input in sector $\mathrm{i}$. When $\hat{v}$ and $\mathrm{G}$ are multiplied, the value at position (i, $\mathrm{j}$ ) indicates the value of production, direct and indirect, enabled in sector $\mathrm{j}$ due to total primary input in sector i. Multiplying this matrix product with $q^{\prime}$ gives $s$, which is a $9165 \times 1$ column vector. It contains the total direct and indirect $\mathrm{Hg}$ emissions enabled in India due to primary inputs to each of the 9165 nation sectors. Summing the values corresponding to the 65 sectors of each nation in this vector gives the Hg emissions enabled in India due to primary inputs of a nation. For instance, in 2014, primary inputs of Saudi Arabia enabled $3.96 \mathrm{t}$ of $\mathrm{Hg}$ emissions in India. Summing the values corresponding to a particular sector from each nation (Australia-Coal, New Zealand-Coal, Rest of Oceania-Coal, etc.) gives the Hg emissions enabled in India due to primary inputs to a sector. For instance, in 2014, total primary inputs to the Coal sector enabled $15 \mathrm{t}$ of $\mathrm{Hg}$ emissions in India.

\section{S6. Extended discussion on Structural Path Analysis (SPA)}

India's Hg emissions in the Leontief input-output model is expressed as shown in equation (10),

$$
q\left(\mathbf{I}+\mathbf{A}+\mathbf{A}^{2}+\cdots+\mathbf{A}^{\mathrm{n}}\right) \hat{y}=q \mathbf{I} \hat{y}+q \mathbf{A} \hat{y}+q \mathbf{A}^{2} \hat{y}+\quad \cdots+q \mathbf{A}^{\mathrm{n}} \hat{y}
$$

and in the Ghosh input-output model, it is expressed as shown in equation (11).

$$
\hat{v}\left(\mathbf{I}+\mathbf{B}+\mathbf{B}^{2}+\cdots+\mathbf{B}^{\mathrm{n}}\right) q^{\prime}=\hat{v} \mathbf{I} q^{\prime}+\hat{v} \mathbf{B} q^{\prime}+\hat{v} \mathbf{B}^{2} q^{\prime}+\ldots+\hat{v} \mathbf{B}^{\mathrm{n}} q^{\prime}
$$

Each term on the right-hand side of the equation (10), $q A^{k} \hat{y}$, is the value of the Hg emissions from the production layer "k" of the supply chain. ${ }^{89}$ The zeroth layer $(\mathrm{k}=0)$ nation-sector is the one directly or indirectly responsible for the emissions. Consider a supply chain as shown in equation (12), 
Here, a part of the final demand of nation A's Construction sector $(\mathrm{k}=0)$ is met by nation B's Mineral products nec sector $(\mathrm{k}=1)$, a part of whose final demand is in turn met by nation C's Coal sector $(\mathrm{k}=2)$. The value corresponding to this supply chain indicates the Hg emissions driven indirectly by Nation A-Construction from Nation C-Coal, through its input requirements from Nation B-Mineral products nec.

Similarly, from the supply point of view, each term on the right-hand side of the equation (11), $\hat{v} \mathrm{~B}^{\mathrm{k}} q^{\prime}$, is the value of the Hg emissions from the production layer "k" of the supply chain. Consider the same supply chain in equation (12) from the supply perspective. Some inputs go from Nation C-Coal to Nation B-Mineral products nec, and some inputs go from Nation B-Minerals nec to Nation A-Construction. The value corresponding to this supply chain indicates the $\mathrm{Hg}$ emissions indirectly enabled by inputs of Nation C-Coal to Nation A-Construction, through Nation B-Mineral products nec.

The largest value of embodied emissions in the consumption-based analysis, or enabled emissions in the income-based analysis, does not necessarily occur in the zeroth layer $(\mathrm{k}=0) .{ }^{90,91}$ In this study, four production layers of the supply chains were extracted (the 0th, 1st, 2nd, and 3rd order) for 2014, and three production layers were extracted for 2004, 2007 and 2011. In and beyond the third layer, the emissions values diminish and are not significantly large. Moreover, there are essentially infinite pathways between any two sectors. ${ }^{89}$ For each production layer, only those paths whose total emissions value is above an arbitrarily chosen threshold value are extracted by a method called "pruning". 90-92 The threshold values chosen in this study are $0.01 \%, 0.001 \%$ and $0.0005 \%$ of the total $\mathrm{Hg}$ emissions value for the 1st, 2nd, and 3rd order of calculations, respectively. The analysis was conducted for each year to identify the top supply chain paths causing $\mathrm{Hg}$ emissions in India.

\section{S7. Comparisons with previous inventories}

Figure S2 shows a comparison of India's Hg emission inventory compiled in this study and previous studies.

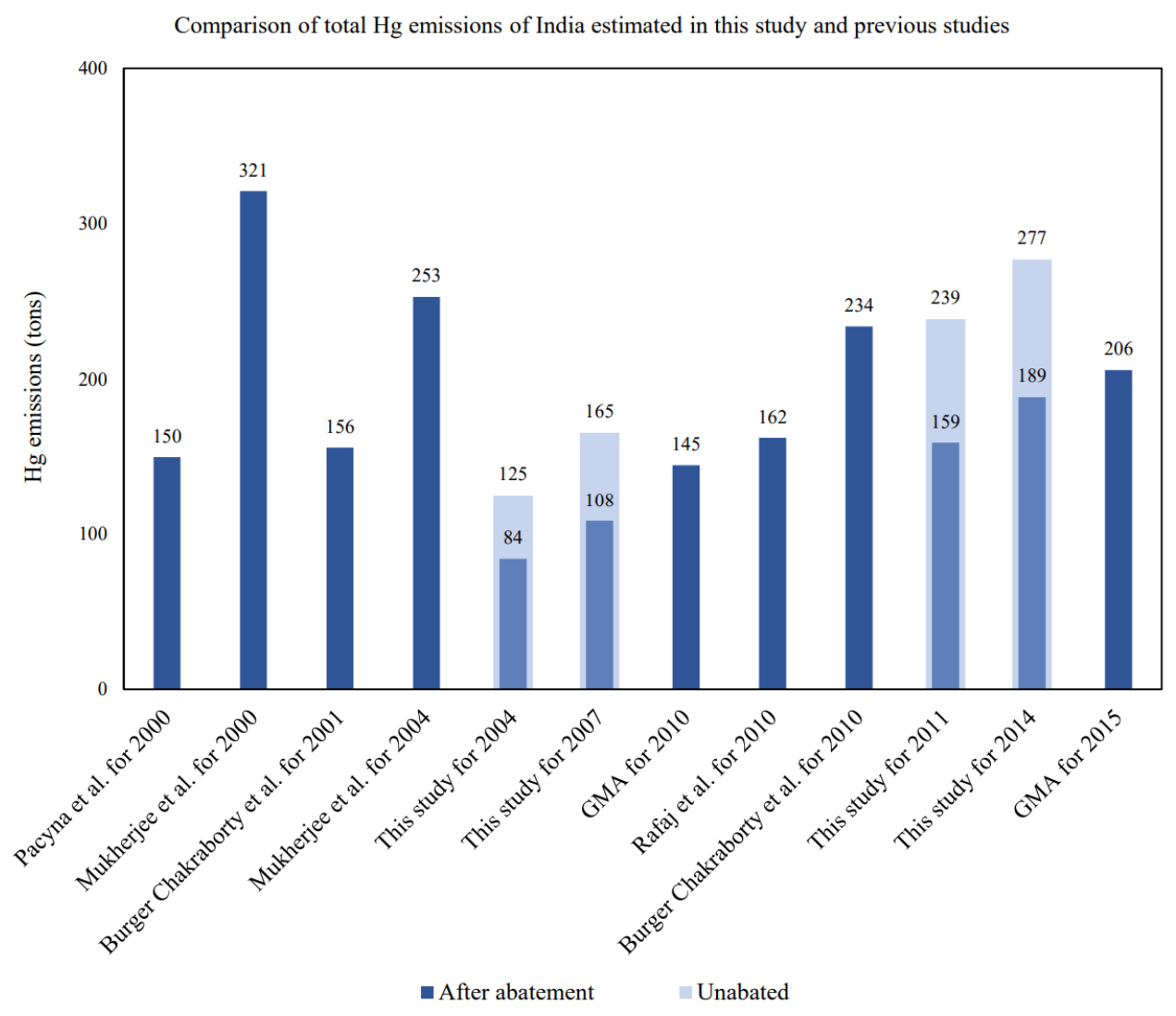

Figure S2. Comparisons of India's Hg emission inventory compiled in this study and previous studies.

The trend of $\mathrm{Hg}$ emissions increase over the years in this study is consistent with the estimates for the years 2010 and 2015 as presented in the Global Mercury Assessment reports ${ }^{1,39}$. The results are also consistent with the Hg emissions estimate for 2010 in Rafaj et al ${ }^{93}$ The Hg emissions 
from industrial sources in 2000 from Pacyna et al. ${ }^{94}$ and in 2004 from this study are comparable. However, the estimate of Hg emissions from stationary combustion for the year 2000 in Pacyna et al. is significantly higher as compared to the estimate for 2004 in this study. This difference can be attributed to the differences in emission factors of activities and the emissions abatement profiles considered, and to the additional consideration of $\mathrm{Hg}$ emissions from residential sources in the former study. Mukherjee et al. ${ }^{3}$ attribute the decrease in $\mathrm{Hg}$ emissions between 2000 and 2004 to the shift from the mercury cell process to the membrane cell technology in the chlor-alkali industry. However, the Hg emissions estimate from their study for the year 2004 is still significantly higher than the estimate in this study. Their emission factors for coal combustion, copper production, lead production and chlor-alkali plants are significantly higher than those considered in this study. The exception is zinc production whose emission factor is considerably lower in Mukherjee et al. The emission factors considered in this study are as per the most recent India-specific data available. Moreover, the estimation of $\mathrm{Hg}$ emissions from wastes in Mukherjee et al. is based on generic emission factors for burning of municipal solid waste (MSW), medical waste and e-waste, which results in a much higher emissions value especially due to the high quantity of annual MSW generation in India. This study follows the approach in the GMA 2018 report and considers the quantity of Hg products entering the waste stream in a year, similar to the approach in Burger Chakraborty et al. ${ }^{25}$ The higher value of total Hg emissions estimated by Burger Chakraborty et al. as compared to this study can mainly be attributed to the difference in emission factor for coal combustion in power plants, and to the consideration of stocks of $\mathrm{Hg}$-containing products accumulating in society which eventually enter the waste stream. Burger Chakraborty et al. consider an emission factor of $0.272 \mathrm{~g} / \mathrm{t}$ of coal combusted in power plants as well as industries. In this study, following the GMA 2018 report $^{1}$, an emission factor of $0.14 \mathrm{~g} / \mathrm{t}$ of coal combusted is used for power plants and $0.272 \mathrm{~g} / \mathrm{t}$ is used for industrial coal combustion. The emission factor considered for coal combustion in power plants is obtained from a UNEP/CIMFR-CSIR study ${ }^{40}$ that tested the mercury content of 66 feed coal samples from eight coalfields supplied to Indian thermal power plants. Other differences between the inventories of this study and Burger Chakraborty et al. are related to $\mathrm{Hg}$ emission abatement. The former assumes that $95 \%$ of $\mathrm{Hg}$ emissions in cement plants are captured in the kiln dust according to the findings of a study on a Slovenian cement plant ${ }^{95}$, whereas this study assumes that about $25 \%$ of the $\mathrm{Hg}$ is captured using electrostatic precipitators. This assumption is based on India-specific information from a study by the United Nations Environment Programme ${ }^{96}$. Further, Burger Chakraborty et al. assume that only $11 \%$ of the $\mathrm{Hg}$ is captured from the total emissions in coal power plants and other coal combustion. A similar level of emissions reduction is assumed for iron and steel industries and in metal production industries in their study due to insufficient data. This study assumes a higher level of emissions reduction from coal combustion in power plants, and production of copper, lead and zinc (refer Table S4). 


\section{REFERENCES}

(1) Arctic Monitoring and Assessment Programme (AMAP)/ United Nations Environment Programme (UNEP) Chemicals and Health Branch. Technical Background Report to the Global Mercury Assessment 2018; AMAP/ UNEP: Oslo, Norway/ Geneva, Switzerland, 2019.

(2) International Energy Agency. World Energy Statistics, 2018 Edition; 2018.

(3) Mukherjee, A. B.; Bhattacharya, P.; Sarkar, A.; Zevenhoven, R. Mercury Emissions from Industrial Sources in India and Its Effects in the Environment. In Mercury Fate and Transport in the Global Atmosphere: Emissions, Measurements and Models; Mason, R., Pirrone, N., Eds.; Springer US: Boston, MA, 2009; pp 81-112.

(4) McDougall, R.; Lee, H.-L. Chapter 17: An Energy Data Base for GTAP. In Global Trade, Assistance, and Production: The GTAP 6 Data Base; Global Trade Analysis Project (GTAP): Department of Agricultural Economics, Purdue University, West Lafayette, IN, 2006.

(5) Annual Report 2008-2009; Ministry of Steel, Government of India.

(6) Annual Report 2015-2016; Ministry of Steel, Government of India.

(7) U.S. Geological Survey Minerals Yearbook-2008; U.S. Department of the Interior, U.S. Geological Survey (USGS).

(8) U.S. Geological Survey Minerals Yearbook-2011; U.S. Department of the Interior, U.S. Geological Survey (USGS).

(9) U.S. Geological Survey Minerals Yearbook-2015; U.S. Department of the Interior, U.S. Geological Survey (USGS).

(10) Annual Report 2015-2016; Ministry of Mines, Government of India.

(11) Annual Report 2016-2017; Ministry of Mines, Government of India.

(12) U.S. Geological Survey Minerals Yearbook-2016; U.S. Department of the Interior; U.S. Geological Survey (USGS).

(13) Indian Minerals Yearbook 2012; Indian Bureau of Mines, Ministry of Mines, Government of India.

(14) World Chlorine Council. WCC report to UNEP on chlor-alkali partnership 2002-2016 Data. https://worldchlorine.org/unep-chlor-alkalimercury-partnership/reporting-on-mercury-use/ (accessed Feb 17, 2020).

(15) Minimising Release and Environmental Implications of Chlorine and Its Compounds; Central Pollution Control Board (CPCB), Ministry of Environment \& Forests, Government of India: New Delhi, Sept, 2008.

(16) Federation of Indian Chambers of Commerce and Industry (FICCI). There is an urgent need to enhance the competitiveness of Indian PVC and Caustic Soda industry. FICCI Media Division Press Release. https://ficci.in/pressrelease-page.asp?nid=2238 (accessed April 5, 2021).

(17) Agrawal, A.; Sinha, S. Mercury in Our Mouth: An Estimation of Mercury Usage and Release from the Dental Sector in India; Toxics Link: New Delhi, India, 2012.

(18) Oral Health in India: A Report of the Multi Centric Study; Directorate General of Health Services, Ministry of Health \& Family Welfare, Government of India/ World Health Organization, Dec, 2007.

(19) The World Bank. World Development Indicators. https://data.worldbank.org/.

(20) Yadav, S.; Rawal, G. The Current Status of Dental Graduates in India. Pan. Afr. Med. J. 2016, 23, 22.

(21) Sandesh N; Mohapatra AK. Street Dentistry: Time to Tackle Quackery. Indian J. Dent. Res. 2009, 20 (1), 1-2. 
(22) N. K Ahuja; Renu Parmar. Demographics \& Current Scenario with Respect to Dentists, Dental Institutions \& Dental Practices in India. Ind.

J. Dent. Sci. 2011, 3 (2), 8-11.

(23) World Health Organization (WHO). World Health Statistics 2018: Monitoring Health for the SDGs, Sustainable Development Goals; WHO: Geneva, 2018.

(24) Dental Council of India in collaboration with Ministry of Health \& Family Welfare, Government of India. National Oral Health Survey \& Fluoride Mapping 2002-2003; Dental Council of India: New Delhi, 2004.

(25) Chakraborty, L.B.; Qureshi, A.; Vadenbo, C.; Hellweg, S. Anthropogenic Mercury Flows in India and Impacts of Emission Controls. Environ. Sci. Technol. 2013, 47 (15), 8105-8113.

(26) Chatterjee. S. Electronic Waste and India. Department of Information Technology, Ministry of Electronics \& Information Technology, Government of India: New Delhi.

(27) Khattar, V.; Kaur, J.; Chaturvedi, A.; Arora, R. E-Waste Assessment in India: Specific Focus on Delhi (A Quantitative Understanding of Generation, Disposal \& Recycling of Electronic Waste); German Organisation for Technical Cooperation ～(GTZ)/ Manufacturers' Association for Information Technology (MAIT)/ Research-based Consultancy for B2B and technology Markets BIRD (IMRB): Nov, 2007.

(28) Baldé, C. P.; Wang, F.; Kuehr, R.; Huisman, J. The Global E-Waste Monitor-2014; United Nations University, IAS - SCYCLE: Bonn, Germany, 2015.

(29) Betne, R.; Rajankar, P. Toxics in That Glow: Mercury in Compact Fluorescent Lamps (CFLs) in India; Toxics Link: New Delhi, 2011.

(30) Electric Lamps and Component Manufacturers Association of India (ELCOMA). Annual Manufacturing Trends in India by Lamps Category (Lighting Industry in India Year 2013). http://www.elcomaindia.com/wp-content/uploads/Final_2013_Lighting_Industry_India.pdf (accessed April, 2021).

(31) Electric Lamps and Component Manufacturers Association of India (ELCOMA). Annual Manufacturing Trends in India by Lamps Category (Lighting Industry in India Trend 2010 - 2017). http://www.elcomaindia.com/wp-content/uploads/Lighting-Industry-India-2017.pdf (accessed April, 2021).

(32) Department of Commerce, Ministry of Commerce and Industry, Government of India. Export Import Data Bank. https://commerce.gov.in/trade-statistics/.

(33) Central Pollution Control Board (CPCB). Mercury- Environmental Implications \& Toxicity. CPCB: New Delhi, Nov, 2009.

(34) Sinha, S.; Das, K. Mercury Free India: Right Choices; Toxics Link: New Delhi, 2014.

(35) Recharged to Glow. Motilal Oswal Securities Ltd: Mumbai, Dec, 2015.

(36) Wankhede, K. K. Household Batteries: Discharging Toxins. Hazardous Waste Factsheet number 23; Toxics Link: New Delhi, Dec, 2004.

(37) Sathaiyan, N.; Nandakumar, V.; Ramachandran, P. Hydrometallurgical Recovery of Silver from Waste Silver Oxide Button Cells. J. Power Sources 2006, 161 (2), 1463-1468.

(38) Arctic Monitoring and Assessment Programme (AMAP)/ United Nations Environment Programme (UNEP) Chemicals Branch. Technical Background Report for the Global Mercury Assessment 2008; AMAP/ UNEP: Oslo, Norway/ Geneva, Switzerland, 2008. 
(39) Arctic Monitoring and Assessment Programme (AMAP)/ United Nations Environment Programme (UNEP) Chemicals Branch. Technical Background Report for the Global Mercury Assessment 2013; AMAP/ UNEP: Oslo, Norway/ Geneva, Switzerland, 2013.

(40) United Nations Environment Programme (UNEP) Chemicals Branch. Assessment of the Mercury Content in Coal Fed to Power Plant and Study of Mercury Emissions from the Sector in India; UNEP: Geneva, Switzerland, 2014.

(41) National Electricity Plan; Central Electricity Authority (CEA), Ministry of Power, Government of India: New Delhi, Jan, 2018.

(42) Tewalt, S.J.; Belkin, H.E.; SanFilipo, J.R.; Merrill, M.D.; Palmer, C.A.; Warwick, P.D.; Karlsen, A.W.; Finkelman, R.B.; Park, A.J.; comp. Chemical analyses in the World Coal Quality Inventory, Version 1. Open-File Report 2010-1196; U.S. Department of the Interior, U.S.

Geological Survey (USGS): Virginia, 2010.

(43) Yoshida, M; Kishimoto, T; Yamamura, Y; Tabuse, M; Akama, Y; Satoh, H. Amount of mercury from dental amalgam filling released into the atmosphere by cremation. (Nihon Koshu Eisei Zasshi) Japanese Journal of Public Health 1994, 41 (7), 618-624.

(44) Windham, B. Mercury Exposure Levels from Amalgam Dental Fillings; Documentation of Mechanisms by Which Mercury Causes over 40 Chronic Health Conditions; Results of Replacement of Amalgam Fillings; and Occupational Effects on Dental Staff. 2002.

(45) Keller, M. Assessment of Gold Recovery Processes in Bangalore, India and Evaluation of an Alternative Recycling Path for Printed Wiring Boards: A Case Study. Diploma thesis, Institute for Spatial and Landscape Planning, Regional Resource Management, ETH, Zurich, 2006.

(46) Electric Lamps and Component Manufacturers Association of India (ELCOMA). ELCOMA Vision 2020. http://www.elcomaindia.com/ (accessed Mar, 2021)

(47) Central Pollution Control Board (CPCB). Environmentally Sound Management of Mercury Waste Generated from the Health Care Facilities. CPCB: New Delhi, Jan, 2012.

(48) Kumari, R.; Agrawal, A.; Tariq, M. Estimation of Mercury Usage and Release from Healthcare Instruments in India; Toxics Link: New Delhi, 2011

(49) Wankhade, K. K. Mercury in India: Toxic Pathways; Toxics Link: New Delhi, 2003.

(50) Agrawal, A.; Singh, R.; Mahesh, P. Lurking Menace: Mercury in the Health-Care Sector; Toxics Link: 2004.

(51) Recknagel, S.; Richter, A.; Richter, S. Investigation on the Heavy Metal Content of Zinc-Carbon and Alkaline Manganese Dry Cells. Waste Management 2009, 29 (3), 1213-1217.

(52) Battery Waste Management Rules, 2020 (Draft); Ministry of Environment, Forest and Climate Change, Government of India: New Delhi, Feb 20, 2020.

(53) Panasonic Batteries Home Page. https://www.panasonic-batteries.com/en (accessed Mar, 2021).

(54) Pesticides (Prohibition) Order, 2018; Ministry of Agriculture and Farmers Welfare, Government of India: New Delhi, Aug 8, 2018.

(55) Pramanik, S.; Kumar, M.; Qureshi, A. Mercury in Skin-Care Products in India and Consumer Exposure Risks. Regul. Toxicol. Pharmacol. 2021, 121,104870

(56) Annual Report 2019-2020; Central Electricity Authority (CEA), Ministry of Power, Government of India: New Delhi, 2020.

(57) Environment (Protection) Amendment Rules, 2015; Ministry of Environment, Forest and Climate Change, Government of India: New Delhi, Dec 7, 2015 
(58) Garg, V.; Narayanaswamy, D.; Ganesan, K; Viswanathan, B. India's Energy Transition: The Cost of Meeting Air Pollution Standards in the Coal-Fired Electricity Sector; The International Institute for Sustainable Development (IISD): Aug, 2019.

(59) Pachouri, R.; Saxena, A. K. Emissions Control in Thermal Power Stations - Issues, Challenges, and the Way Forward; The Energy and Resources Institute (TERI): New Delhi, 2020.

(60) Environment (Protection) Amendment Rules, 2021; Ministry of Environment, Forest and Climate Change, Government of India: New Delhi, Mar 31, 2021.

(61) Quarterly Review Report- Renovation \& Modernisation of Thermal Power Stations (April-June, 2020); Central Electricity Authority (CEA), Ministry of Power, Government of India: Aug, 2020.

(62) United States Environmental Protection Agency. Mercury and Air Toxics Standards. https://www.epa.gov/mats/cleaner-powerplants\#controls (accessed May, 2021).

(63) Natural Resources Defense Council (NRDC). Summary of Recent Mercury Emission Limits for Power Plants in the United States and China; NRDC: April, 2012.

(64) Bureau of Energy Efficiency (BEE), Ministry of Power, Government of India. Perform Achieve and Trade (PAT). https://beeindia.gov.in/content/pat-3.

(65) Pathways for Accelerated Transformation in Industry Sector: A Report on the Outcome of Cycle-II under Perform, Achieve and Trade (PAT) Scheme; Bureau of Energy Efficiency (BEE), Ministry of Power, Government of India: New Delhi, June, 2020.

(66) Registration of Exemptions for the Products and Processes Listed in Part I of Annexes A and B; Hazardous Substances Management Division, Ministry of Environment, Forest and Climate Change, Government of the Republic of India: New Delhi, April 16, 2018.

(67) Zhu, D.; Asnani, P. U.; Zurbrügg, C.; Anapolsky, S.; Mani, S. Improving Municipal Solid Waste Management in India: A Sourcebook for Policy Makers and Practitioners. The International Bank for Reconstruction and Development / The World Bank: Washington, DC, 2008.

(68) Swati; Thakur, I. S.; Vijay, V. K.; Ghosh, P. Scenario of Landfilling in India: Problems, Challenges, and Recommendations. In Handbook of Environmental Materials Management; Hussain, C. M., Ed.; Springer International Publishing: Cham, 2018; pp 1-16.

(69) Solid Waste Management Rules, 2016; Ministry of Environment, Forest and Climate Change, Government of India: New Delhi, Apr 8 , 2016.

(70) World Business Council for Sustainable Development (WBCSD). Low Carbon Technology Roadmap for the Indian Cement Sector: Status Review 2018; WBCSD: Nov, 2018.

(71) Achievements under Perform, Achieve and Trade (PAT); Bureau of Energy Efficiency (BEE), Ministry of Power, Government of India: New Delhi, May, 2017.

(72) Confederation of Indian Industry (CII). Low Carbon Roadmap for Indian Cement Industry. CII: Hyderabad, May, 2010.

(73) Environment (Protection) (Fifth Amendment) Rules, 2014; Ministry of Environment, Forest and Climate Change, Government of India: New Delhi, Aug 25, 2014.

(74) Environment (Protection) Fourth Amendment Rules, 2016; Ministry of Environment, Forest and Climate Change, Government of India: New Delhi, May 9, 2016. 
(75) Environment (Protection) Third Amendment Rules, 2016; Ministry of Environment, Forest and Climate Change, Government of India: New

Delhi, May 10, 2016.

(76) United Nations Environment Programme (UNEP). Minamata Convention on Mercury; http://www.mercuryconvention.org.

(77) Secretariat of the Minamata Convention on Mercury, Chemicals and Health Branch, United Nations Environment Programme (UNEP). Guidance on Best Available Techniques and Best Environmental Practices. UNEP: Geneva, Sept, 2019.

(78) Environment (Protection) (Third Amendment) Rules, 2012; Ministry of Environment, Forest and Climate Change, Government of India: New Delhi, Mar 31, 2012.

(79) Environment (Protection) Fourth Amendment Rules, 2008; Ministry of Environment, Forest and Climate Change, Government of India: New Delhi, May 30, 2008.

(80) National Resource Efficiency Policy, 2019 (Draft): Charting a Resource Efficient Future for Sustainable Development; Ministry of Environment, Forest and Climate Change, Government of India: New Delhi, July 23, 2019.

(81) World Steel Association. "Energy use in the steel industry" Fact sheet, April 2021.

(82) Steel Scrap Recycling Policy; Ministry of Steel, Government of India: New Delhi, Nov 7, 2019.

(83) Tata Steel. HISarna: Building a Sustainable Steel Industry; HIsarna factsheet nr. 2; Tata Steel: Feb, 2020.

(84) Hall, W.; Spencer, T.; Kumar, S. Towards a Low Carbon Steel Sector: Overview of the Changing Market, Technology, and Policy Context for Indian Steel. The Energy and Resources Institute (TERI): New Delhi, 2020.

(85) Jha, D. N. Mercury to Repair Teeth a Bad Fix for Your Health. Times of India, May 27, 2017.

(86) Sinha, S.; Das, K. Chlorine Industry: Economics of Conversion in India; Toxics Link: New Delhi, Jan, 2012.

(87) Charter on Corporate Responsibility for Environmental Protection: Action Points for 17 Categories of Industries; Central Pollution Control Board (CPCB), Ministry of Environment and Forests, Government of India: Mar, 2003.

(88) Ministry of Environment \& Forests. Partnership Initiative for Pollution Control: Charter on Corporate Responsibility to be released; Press Information Bureau: Mar 12, 2003.

(89) Peters, G. P.; Hertwich, E. G. Structural Analysis of International Trade: Environmental Impacts of Norway. Econ. Syst. Res. 2006, 18 (2), $155-181$.

(90) Treloar, G. J. Extracting Embodied Energy Paths from Input-Output Tables: Towards an Input-Output-Based Hybrid Energy Analysis Method. Econ. Syst. Res 1997, 9 (4), 375-391.

(91) Lenzen, M. A Guide for Compiling Inventories in Hybrid Life-Cycle Assessments: Some Australian Results. J. Cleaner Prod. 2002, 10 (6), $545-572$.

(92) Lenzen, M. Environmentally Important Paths, Linkages and Key Sectors in the Australian Economy. Structural Change and Economic Dynamics 2003, 14 (1), 1-34.

(93) Rafaj, P.; Bertok, I.; Cofala, J.; Schöpp, W. Scenarios of Global Mercury Emissions from Anthropogenic Sources. Atmos. Environ. 2013, $79,472-479$. 
(94) Pacyna, E. G.; Pacyna, J. M.; Steenhuisen, F.; Wilson, S. Global Anthropogenic Mercury Emission Inventory for 2000. Atmos. Environ. 2006, 40 (22), 4048-4063.

(95) Mlakar, T. L.; Horvat, M.; Vuk, T.; Stergaršek, A.; Kotnik, J.; Tratnik, J.; Fajon, V. Mercury Species, Mass Flows and Processes in a Cement Plant. Fuel 2010, 89 (8), 1936-1945.

(96) Division of Technology, Industry and Economics (DTIE), Chemicals Branch, United Nations Environment Programme (UNEP). Study on Mercury Sources and Emissions, and Analysis of Cost and Effectiveness of Control Measures: "UNEP Paragraph 29 Study"; UNEP: Geneva, Switzerland, Nov, 2010 